This is the peer reviewed version of the following article:Dragoni Danilo, Lazzari Valter, and Navone Marco 2010, 'Mutual fund incentive fees: Determinants and effects', Wiley-Blackwell, vol. 39, no. 1, pp. 365-392. which has been published in final form at http://dx.doi.org/10.1111/j.1755-053X.2010.01076.x This article may be used for noncommercial purposes in accordance With Wiley Terms and Conditions for self-archiving' 


\section{Mutual Fund Incentive Fees: Determinants and Effects}

We investigate the how and why of performance fee provisions in a free contracting environment such as the Italian mutual fund market was until 2006. We find weak support for the hypothesis that these provisions emerge as an economically efficient solution in a rational asset management industry plagued by asymmetric information. They appear to emerge mainly as the product of strategic pricing by asset managers wishing to ease market competition, leverage on investors' sentiment, and hedge their cost structure. Alternatively, fears that managers may opportunistically alter funds' investment policies to maximize the option value embedded in the incentive provisions appear unjustified.

Danilo Drago is a Professor at Università della Calabria, SDA Bocconi.

Valter Lazzari is a Professor at the Università Cattaneo, SDA Bocconi.

Marco Navone is an Assistant Professor at the Università Bocconi, SDA Bocconi.

The authors acknowledge the financial support of Carefin, Bocconi University for a related unpublished paper from which this work originates. Lazzari thanks the Cariplo Foundation for a grant supporting this work. The paper benefits from comments received by colleagues attending conferences where it was presented. Our largest debt, however, is to the two referees whose comments improved the paper immensely. Any remaining faults are exclusively ours. 


\section{Introduction}

The reward scheme for asset managers often consists of both management fees and performance fees. The former are set as a percentage of the assets under management (AUM); the latter are a function of the realized return on the managed portfolio.

Hedge fund managers usually earn performance fees on the total realized return. For mutual fund managers, performance fees are typically calculated as a percentage of the differential between their portfolio return and a hurdle variable ${ }^{1}$. If the hurdle variable is the return on a pre-specified normal portfolio defining the investment objective of the fund (benchmark), the performance fee is a percentage of the fund's active return. If the hurdle variable is a proxy of the risk-free rate (an interbank interest rate or a return on an index of treasury bills), the performance fee is a percentage of the fund's excess return. In some instances, the hurdle variable is set as a constant worth a few percentage points, referred to as the hurdle rate.

Performance fees may be either symmetrical (fulcrum fees) or asymmetrical (bonus plan). With fulcrum fees, a manager who outperforms the hurdle variable receives a proportion of the positive differential, while they suffer a symmetrical deduction from the management fee in the case of under performance. Bonus plans, instead, reward out performance without penalizing under performance and offer fund managers an option-like payoff.

The literature on incentive fees offers insights into their influence on managers' investment choices (Carpenter, 2000; Elton, Gruber, and Blake, 2003), on their optimal structure in terms of social welfare maximization (Das and Sundaram, 2002), on their pros and cons as a tool to manage the agency problem arising between investors and managers, the

\footnotetext{
${ }^{1}$ Evans (2008) analyzes the incentive effect of mutual fund manager's personal fund investment. In case of direct investment, of course, the incentive is based on the fund total return.
} 
screening problem of separating good managers from bad, and the signaling problem of conveying credibly any informational advantages managers may possess (Admati and Pfeiderer, 1997; Stremme, 1999; Cuoco and Kaniel, 2000).

These contributions are mainly theoretical since an amendment to the Investment Company Act enacted in 1970 made it illegal in the U.S. for mutual fund managers to charge asymmetric performance fees. Since then, only a handful of U.S. managers have been brave enough to adopt fulcrum fees. Almost everyone opted for a reward scheme based on management fees only, depriving researchers of the data needed for a meaningful empirical investigation into the compensation structure of mutual fund managers agreed upon by investors in a free contracting environment.

In this paper, we overcome the problem of missing data by investigating the Italian mutual fund industry. Until the end of 2006, it was free from relevant regulatory constraints on any compensation scheme fund managers might set. ${ }^{2}$ This free contracting environment for mutual funds' incentive provisions allows us to build a unique database to address the two major empirical issues concerning managers' pay for performance compensation.

First, we investigate the rationale behind the use of incentive fees. The dominant hypothesis in the economic literature suggests performance fees are either a signaling device (Spence, 1973) which fund managers exploit to advertise their ability, or an optimal contracting rule (Holmstrom, 1979) meant to offer managers appropriate incentives to prevent the risk of moral hazard. Following a more managerial perspective, however, we suggest it is worth considering a further rationale for setting performance fees. That is to weaken price competition among managers through a less transparent and harder to compare

\footnotetext{
${ }^{2}$ As of January 2007, all Italian mutual funds must comply with a much tighter regulation on incentive fee schemes aimed at avoiding the risk that these provisions end up rewarding volatility rather than performance.
} 
pricing policy. We then assess the relative explanatory power each approach has for this issue.

Second, we compare the dynamics of portfolio returns for funds with and without incentive provisions to verify whether asset managers, with their compensation tied to performance, opportunistically adjust their portfolio decisions to optimize the value of the option embedded in the bonus plan to which they are entitled, thus pushing the risk-return profile of their fund far from the optimal one. This possibility, first suggested by Starks (1987) and Cohen and Starks (1988), has not yet been fully tested. To the best of our knowledge, its only empirical investigation is in the noteworthy work of Golec and Starks (2004), which studies the change in fund behavior caused by the banning of asymmetric fees in the U.S. in 1971. We exploit the opportunities offered by the free contracting environment of Italy until 2006 to assess, in more detail, both the types of moral hazard risk which may originate from the manager reward scheme and how material they can be in practice. In fact, this risk may be not as great as a straightforward standard option theory would suggest. In contrast with a standard call option holder, the manager rewarded with a bonus plan is not facing a purely asymmetric payoff. Opportunistic behavior leaves them exposed to a relevant downside risk in terms of the potential loss of reputational capital and of the possible shrinking base of their AUM.

In investigating the possible rationale for adopting an incentive provision, we find that with no major regulatory constraints set on the compensation structure for mutual fund managers this choice strongly depends on the type of fund managed. About nine out of ten equity funds charge performance fees; whereas, just one in two bond funds do. The percentage drops even further among money market funds (less than one in ten charges such a fee). This cross-sectional evidence lends some support to the theory of incentive provisions as an optimal contracting device. According to Holmstrom (1979), when the agent's action is 
not observable, but can only be inferred from the final outcome, the first best risk-sharing compensation scheme is not viable as it doesn't produce sufficient incentive for the agent to exert extra effort. Under these conditions, the compensation agreement is usually a second best solution where the agent bears a certain level of risk owing to a performance-linked compensation. On a related issue, Gaver and Gaver (1995) find a similar result demonstrating that executives in firms with abundant investment opportunities receive a larger proportion of their compensation from long-term incentive tools such as restricted stock grants and stock options grants.

We also find that in a free contracting environment, there is an overwhelming preference for some form of bonus plan over fulcrum fees. The latter never occurs in our sample, casting serious doubts over the signaling function sometimes assigned to performance fee provisions. To be credible and reliable, a signal has to be costly to send, even more so for the "bad type" of manager. Fulcrum fees would, in that instance, be much more effective than bonus plans. Yet they seem to appeal to no one. Moreover, performance fees prove to be ineffective in discriminating good from bad managers. In certain fund categories, this type of provision is almost universally used, permitting no discrimination between competing products. In other categories, funds with performance fees fail to show better performance when compared with directly competing funds without them.

Our empirical findings provide full support for the managerial perspective that sees the incentive provisions as the outcome of strategic pricing policies pursued by the fund managers. The cost and the ownership structure of the investment companies, as well as the investors' sentiment, the size of the funds, and the size of the investment companies, carry strong explanatory power regarding the presence of incentive provisions across funds.

In investigating the possibility that managers with compensation tied to performance act opportunistically, we find no evidence for any of the three moral hazard risks that 
regulators fear: 1) funds with an incentive provision are no riskier than similar funds without it, 2) managers do not alter the risk profile of their funds according to the realized performance while approaching the incentive fee calculation date, and 3) investment companies managing a portfolio of funds with similar mandates do not lower their funds' correlations to stabilize their stream of income from performance fees. It may well be the case that the risk of losing reputational capital and a shrinking base of AUM offsets the desire to exploit opportunistically the option-like payoff created by the incentive provision.

The paper is organized as follows. Section II discusses how Italian funds charge incentive fees according to the industry practice. Section III outlines the presence of incentive provisions in the Italian mutual fund industry. Section IV introduces the logistic models used to analyze why funds charge incentive fees and details the proposed explanatory variables. Section V explains the results. Section VI investigates the effects of incentive fees on fund managers' investment choices, assessing how material the moral hazard risk is. Section VII summarizes and concludes.

\section{The Structure of Asymmetric Incentive Fees}

An asset manager charging both a management and an asymmetric performance fee earns:

$$
A F=a_{0}+a_{1} \operatorname{Max}\left(R_{p}-R_{b}-K ; 0\right)
$$

where $A F$ is the total payoff for the manager, $a_{0}$ is the management fee, $a_{l}$ is the participation rate, $R_{p}$ is the fund return, $R_{b}$ is the benchmark return (or the change in any other prespecified hurdle variable), and $K$ is the return in excess of the hurdle variable needed to claim 
the right to a performance fee. $K$ is often set equal to zero, allowing the manager to collect a performance fee whenever fund returns exceed the reference portfolio returns.

This payoff is proportional to the payoff of an option offering the right to exchange the reference portfolio for the fund portfolio (spread option) with a scale factor equal to the participation rate. Option theory provides useful insights for estimation of the value of these compensation schemes. It stops short, though, of providing a perfect pricing since there is no possibility of hedging the underlying position on a frictionless market.

Since compensation schemes with asymmetric performance fees amount to option claims, their value to managers, as well as their cost to investors, is an increasing function of the underlying asset's volatility. In our case, it is the volatility of the spread between the fund portfolio return and the reference portfolio return (herein referred to as spread volatility).

Should the reference portfolio consist of the risk-free asset only, the spread volatility becomes the fund volatility itself. The same holds true if no hurdle variable is set. When the fund benchmark is chosen as the reference portfolio, the spread volatility becomes the fund's tracking error which is a measure of the relative risk (with respect to the benchmark) a manager accepts in order to generate positive active returns (Gupta, Prajogi, and Stubbs, 1999), as well as a tool for both an ex post performance evaluation and an ex ante definition of the fund's investment policies (Blitz and Hottinga, 2001).

It may appear strange that investors agree to a compensation scheme based on a rule that rewards the risk of the fund, either in an absolute or in a relative form. Managers may consciously pursue investment policies that widen the spread volatility to raise the value of their performance fees. Starks (1987) demonstrates that a symmetric fee strictly dominates a bonus plan in giving the manager the incentive to assume the optimal risk level for the investors. The asymmetric fee, shading the manager from the downside of a bad performance, induces excessive risk-taking. 
This moral hazard risk is not as large as it seems. In contrast with a standard call option holder, the manager remains exposed to a downside risk in terms of the loss of reputational capital and lower management fee income due to a shrinking AUM base. Chevalier and Ellison (1997) and Sirri and Tufano (1998) prove that past performances are positively correlated with future fund inflows. Since the management fee is proportional to AUM, larger tracking errors increase the probability of poor performance relative to the benchmark, putting at risk the growth of the fund and the related manager's income. Fund rankings published in the press amplify the risk (Goodwin, 1998; Goriaev, Palomino, and Prat, 2000). According to Chevalier and Ellison (1999), managers working for investment companies are concerned about their career prospects. In the case of poor performers, they may be fired or have their career cut short with an ensuing depreciation of their human capital.

Even though managers remain exposed to some downside risk, the fear that asymmetrical incentive fees still provide them with an inappropriate incentive for tilting their investment strategies toward excessive risk prompted the U.S. Congress to forbid bonus plans and to allow only fulcrum fees. A variety of bonus plans spring from the structure shown in Equation (1). As an example, in the regulatory environment we analyze, managers are not allowed to collect performance fees if the return on the fund is negative, regardless of the active return generated by the manager. ${ }^{3}$ To comply with this regulation, the fee structure must set a lower limit equal to zero either on the fund return or on the benchmark return, making the manager's payoff respectively equal either to:

$$
A F=a_{0}+a_{1} d \operatorname{Max}\left(R_{p}-R_{b}-K ; 0\right)
$$

\footnotetext{
${ }^{3}$ See Bank of Italy Supervisory Bulletin No. 7, 1998 and No. 4, 2001. For the Regulator, incentive fees should be charged only if the performance is satisfying for the investors, and a negative return never qualifies as such.
} 


$$
A F=a_{0}+a_{1} \operatorname{Max}\left(R_{p}-\operatorname{Max}\left(R_{b} ; 0\right)-K ; 0\right)
$$

where $\mathrm{a}_{0}$ is the management fee and $d$ is a binary variable worth one if $R_{p}>0$ and zero if otherwise.

In both cases, the regulatory constraint is satisfied with $K \geq 0$. Since the manager cannot benefit from incentive fees when portfolio returns are less negative than benchmark returns, both schemes are worth less than the standard scheme in Equation (1). The structure in Equation (3) is less generous to the manager than that of Equation (2) since it allows the manager to earn the incentive fee only if the returns on both the benchmark and the fund are positive. The structure in Equation (2) only requires the fund return to be positive.

A second variation on the basic structure sets the participation rate according to a rising scale that is dependent upon the fund return in excess of the reference portfolio return (step-by-step incentive fee). This could happen should the participation rate be set at $10 \%$ when the active return falls between $1 \%-2 \%$, at $20 \%$ if it falls between $2 \%-3 \%$ and at $30 \%$ if it exceeds $3 \%$. The payoff of a step-by-step asymmetric performance fee is similar to the payoff of a portfolio of binary (digital) spread options.

An additional type of incentive scheme sets a ceiling on the manager's payoff. Whenever this happens, the manager is long in a bull spread strategy. Its value is less exposed to changes in the spread volatility than is the value of a corresponding asymmetrical fee without any upper bound on the payoff.

The value of a bonus plan is also highly dependent on the reference period set for its calculation. Incentive fees are synchronous if the calculation period matches the period between two successive payment dates. A synchronous quarterly fee is paid four times a year 
on the basis of the excess return earned in each quarter. Incentive fees are asynchronous if their calculation period is different from their payment cycle (e.g., when the fee is paid quarterly based on the annual performance ending on the day when the payment is due). In our sample, we find both asynchronous and synchronous performance fee provisions with a calculation period ranging from one month to a full calendar year. Drago, Lazzari, and Navone (2008) illustrate how, ceteris paribus, the value of an incentive provision is higher when the fees are asynchronous and the calculation period is shorter.

The following citation, taken from the prospectus of a family of Italian funds managed by Pioneer Investment (the investment company of Unicredit Group) refers to an annual synchronous performance fee and reads as follows (adapted from the original Italian text):

The investment company is entitled to perceive the performance fee whenever the change in the value of a fund unit exceeds the change in the Banca Fideuram Index of the corresponding category of funds ${ }^{4}$. The performance fee is equal to $25 \%$ of the above mentioned excess return and is paid by the fund on the first working day following the end of the yearly calculation period. To this end, during each year, the investment company proceeds on a daily basis to calculate the return on the reference index since the previous year-end and to compare it with the corresponding return recorded by each fund's unit at the end of each trading day.

This quote underlines an important feature of the incentive fee mechanism shared by the Italian funds until 2006, the non-cumulative property of the realized fund return and of the

\footnotetext{
${ }^{4}$ The Banca Fideuram Indices are informative regarding the mean return earned by all Italian funds of any given category.
} 
hurdle variable. Neither of them is carried over from one calculation period to the next. ${ }^{5}$ Whenever a new period starts (start date), the calculation procedure loses its memory of any past under performances of the fund with respect to the hurdle variable. The exchange option implied by the provision is always reset to be at the money on each start date. ${ }^{6}$

The asset manager may be paid the incentive fee for any calculation period when, in fact, the cumulative performance of the fund from the subscription date till the redemption date falls short of the cumulative change in the hurdle variable and may even be negative. In fact, let's suppose the fund realizes a negative return of $8 \%$ and under performs the hurdle variable by $5 \%$ in the first calculation period that an investor is in the fund. The manager would not collect a performance fee. In the subsequent calculation period, however, he does so even if the fund records a positive return of just $4 \%$ and recovers only three of the five percentage points return shortfall recorded in the previous period with respect to the hurdle variable. Despite a realized holding period return of $-4.32 \%$ and a $2 \%$ overall under performance, this investor still rewards the manager with a performance fee.

The above citation also indicates that performance fees are charged to the fund on a daily basis. At the end of each trading day, the incentive fee is computed on the cumulative fund performance recorded since the beginning of the current calculation period. This amount is charged to the fund and recorded as one of its liabilities (negative accrual), lowering the net asset value (NAV) at which its shares can be subscribed or redeemed. The process is repeated daily until the last day of the calculation period (calculation date) when the fund settles its debt by paying the manager the performance fees accrued over the period. In fact, the next passage of the cited prospectus reads as follows:

\footnotetext{
${ }^{5}$ This prompted the Bank of Italy to introduce tighter regulations on incentive fees.

${ }^{6}$ Should the provision set a fixed hurdle rate, at any start date the call option would be reset at the same out of the money level.
} 
On the basis of this difference (fund return minus reference index return), the investment company calculates the performance fee it is entitled to and compares it with the corresponding sum accrued over the preceding days. Should a positive difference emerge, it would be debited to the fund, while should it be negative, it would be credited to the fund.

In the free contracting environment of the Italian mutual fund industry, two methodologies are used to deal with the interim flows of new subscriptions between two consecutive calculation dates in quantifying the incentive fee due to the manager. Because of the "mutual" attribute of these pooled investment vehicles, the fee is accrued for each unit based on the performance of the unit from the relevant start date and not from its subscription date. While some funds may quantify the total incentive fee for which they are liable by multiplying this unit fee by the number of units outstanding on the calculation date (point calculation method), other funds base the calculation on either the daily average value of the AUM or the daily average number of shares outstanding during the whole calculation period (averaging calculation method). With the former procedure, even fund shares issued on the day preceding the calculation date are liable for the fee due for the performance delivered over the entire calculation period. On those shares, therefore, the manager would be rewarded for a performance that was not delivered. This problem is mitigated, but does not disappear, if the latter procedure is adopted.

Thus, the payoff of a performance fee provision is sensitive to the combined effect of three interacting variables: 1) the time profile of the fund interim net inflows, 2) the time distribution of the return realized by the fund during the calculation period, and 3) the calculation procedure used to take into account the changing number of fund units outstanding. 


\section{Incentive Fees in the Italian Mutual Fund Industry}

The reference universe for our analysis consists of 970 mutual funds chartered in Italy and active at the end of 2004 . Their assets amount to $€ 357,255$ billion with an average of $€$ 368 million of AUM for each fund. They are managed by 51 investment companies incorporated according to Italian law as società di gestione del risparmio (SGR).

We build our database by combining two different sources. The first one is MoneyMate, one of the leading providers of mutual fund data for many European countries and the only survivorship bias-free database for the Italian market. Return on market indices used as hurdle variables by the funds with incentive fees are obtained from Datastream. Information on the fee structure is hand collected from the funds' prospectuses.

Most of the investment companies are part of larger banking or insurance groups that sell fund shares directly to the public. Two of them are jointly owned by several cooperative banks that take care of the distribution through their network of branches. The remaining companies (called "independent"), raise capital for the funds they manage through either a distribution agreement with third parties (banks and independent financial advisors) or direct sales.

Panels A and B of 
Table I illustrate how investment companies that belong to banking groups dominate the market. They manage $81.8 \%$ (89.5\% when the companies jointly owned by the cooperative banks are also taken into consideration) of the AUM by the whole industry and are responsible for $68.1 \%$ of the funds registered in Italy.

Insert Table I about here.

When they are compared with their competitors, their offerings are skewed toward funds specializing in fixed income products (money market and bond funds), as well as toward hybrid funds. They maintain, instead, a smaller fraction of their AUM in equity and total return funds.

Panel C of 
Table I indicates the size of the management fee. Across the entire population of funds it averages $1.46 \%$, ranging from a mean of $0.55 \%$ among the money market funds to a mean of $1.88 \%$ among the equity funds. Funds managed by independent investment companies tend to charge lower management fees than other funds of comparable type.

Performance fee provisions are usually justified on the grounds of economic efficiency in an asymmetric information environment either as an optimal contracting device to elicit the manager's best effort, or as a signaling device to allow the public to separate good managers from bad managers. In this paper we suggest an alternative hypothesis: from a managerial perspective, we believe they should be regarded as part of a rational pricing strategy profit-maximizing investment companies implement in order to increase their revenue and to soften price competition having regard to their cost and ownership structure, to the securities market conditions and to their market power

Should incentive provisions serve mainly as an optimal contracting device between the risk-neutral principals and a risk-averse agent in an asymmetric information environment, compensation would be made more dependent on realized performance (e.g., the agent has more opportunity to determine performance). Otherwise, the marginal benefit of providing the agent with the incentive to exert an unobservable effort would be more than offset by the marginal cost of giving up the first best optimal risk-sharing solution consisting of a flat reward.

In the mutual fund industry, investors may be thought of as risk-neutral principals, assuming their wealth is fully diversified. Fund managers are better seen as risk-averse agents since much of their income is tied up in their professional activity. The correlation among the assets included in the fund's investable universe acts as proxy for the power of active management to determine portfolio performance. The more correlated their returns are, the lower the gain from fostering the manager's effort when compared with the cost of giving up 
optimal risk-sharing through performance pay. If so, incentive fees should be the standard among equity funds and total return funds, where more is to be gained from proper stock picking and market timing ability. They should be less common among hybrid funds and bond funds and should be the least popular among money market funds.

The Italian mutual fund industry fits the pattern suggested by the optimal contracting hypothesis. Table II offers a breakdown of our fund population according to their investment specialization as defined by Assogestioni, the trade association of Italian investment companies.

Insert Table II about here.

At the end of 2004, 672 of the 970 existing funds charged incentive fees. While accounting for $69.3 \%$ of the total number of active funds, they were responsible for just $48 \%$ of the total AUM by the industry. They all employed some form of bonus plan. No fulcrum fee scheme was found.

More than eight out of ten equity funds and total return funds charge performance fees. The same holds for just two out of three hybrid funds and for one out of two bond funds. Performance fees are rare among money market funds; only one out of ten charges them.

There is just one piece of evidence from the Italian market that we find hard to explain within the efficient contracting framework. With the exception of total return funds, in Italy all mutual funds must state in their prospectus their normal portfolio, or benchmark, to let current and potential subscribers identify the risk/return profile the manager is deemed responsible for providing. We would then expect incentive fees to be set as a function of the realized portfolio returns in excess of the benchmark's return. Instead, only three out of four funds with a bonus plan follow this practice. The remaining $25 \%$ charge incentive fees on the 
portfolio return exceeding the value of a hurdle variable unrelated to the investment task the manager is contractually obliged to perform, such as 1) the average rate of return of all other funds in the same Assogestioni category that usually groups together funds with different investment styles (i.e., equity funds specializing in large cap value stock and equity funds specializing in small cap growth stocks), 2) either the return on an index of treasury bills and notes or the Euribor rate intended as a proxy of a risk-free rate often increased by a few percentage points representing a fair risk premium, 3) the return realized by the fund itself ' $N$ ' periods earlier, and 4) the rate of inflation, as measured by the consumer price index.

All else being equal, these reward schemes increase the value of the manager's compensation since the return on a fund is less correlated with the above mentioned variables than with its own benchmark. It is surprising that investors find acceptable compensation schemes unrelated to the investment objective contractually agreed upon. They allow managers to collect performance fees that reward the risk borne by the fund rather than the manager's ability and effort.

The economic literature on mutual funds also suggests that incentive fees may serve as a signaling device used by investment companies with superior management ability to separate themselves from the others and enjoy a larger net inflow of capital. If so, for each category group we should expect to find this type of provision only in a fraction of the competing funds. There would be no reason to expect a great variation of this fraction across category groups. This is not the case in Italy. Performance fees are an almost universal trait among equity funds, total return funds, and hybrid funds failing to act as an effective separating device.

According to the signaling hypothesis, funds with incentive provisions should deliver better performance on average and attract a larger inflow of capital, standing out by virtue of their larger asset size when compared with similar funds with no such provision. Elton et al. 
(2003) found that among U.S. bond and stock mutual funds, those charging incentive fees make up less than $2 \%$ of the total, but account for more than $10 \%$ of the AUM by the industry and deliver a marginally superior risk-adjusted performance. The evidence from the Italian market does not lend similar support to the signaling hypothesis. Among equity, hybrid, and total return funds, those with a performance fee do not appear to grow significantly larger than those without it. They account for $83 \%$ of the population in the equity group, $67 \%$ in the hybrid group, and $83 \%$ in the total return group. They claim $87 \%, 72 \%$, and $80 \%$ of the total AUM by their respective categories. In the bond and money market categories, as Table II indicates, funds with incentive fees fail to attract cash inflow and remain smaller in size than the others. While $9.1 \%$ of money market funds and $52.6 \%$ of bond funds charge performance fees, they are responsible for just $3.8 \%$ and $45.7 \%$ of the total AUM by their respective category group.

The divergent evidence provided by the U.S. and the Italian experiences of the role of incentive provision as a suitable signal used by good managers to single themselves out most probably depends on the different regulatory settings concerning fund managers' compensation. While U.S. securities law requires incentive fees to take the form of fulcrum fees, in the Italian setting that we analyze, managers can freely opt either for fulcrum fees or for bonus plans. Fulcrum fees (which penalize underachievers) strictly dominate bonus plans (which don't) as a signaling tool for managers. Yet, taking advantage of milder regulations, all Italian managers opt for bonus plans over fulcrum fees, showing little concern regarding the effectiveness of their compensation scheme as a signaling tool. In a free contracting environment, performance fee provisions do not prove to be a useful tool to reach a separating equilibrium in which good and bad managers can be correctly identified.

The performance fee is a contingent reward. As we discuss in a companion paper (Drago et al., 2008), the value of an incentive provision is highly sensitive to many 
apparently minor technical details (participation rate, hurdle variable, and frequency of computation), the relevance of which the man in the street finds hard to understand and compare ex ante across competing products. When compared with a management fee, an incentive provision makes it more difficult for investors to rank fund products according to their cost. Thus, we suggest that performance fees may be better understood as part of a strategic pricing policy. Profit-maximizing managers aim to increase their revenue stream by softening price competition and exploiting investors' market sentiment, while giving proper consideration to their market power and cost structure.

Incentive provisions make the pricing more opaque for the typical mutual fund customer who is often an unsophisticated retail investor, as revealed by an Assogestioni report (2005). Over $70 \%$ of the assets invested in Italian mutual funds come from retail investors. Forty percent of Italian families own mutual fund shares and 53\% of investors allocate to mutual funds less than $€ 15,000$. In our companion paper, we also found the average option value of performance provisions across our equity fund population to be $0.43 \%$ of the AUM on an annual basis. It accounts for one-fifth of the equity fund manager total compensation. The remaining four-fifths are due to the management fee.

The evidence from the Italian market lends some prima facie support for this managerial view. While both hypotheses based on economic efficiency suggest a certain degree of substitution between management and performance fees, should the managerial interpretation prevail, we would not expect, on average, to find lower management fees in funds that also charge performance fees.

Table III provides evidence that Italian fund managers are unwilling to give up part of their management fees in exchange for collecting performance fees.

Insert Table III about here. 
In most categories, the average management fee is not significantly different when compared to funds with and without incentive fees. The t-test rejects the hypothesis of equal average management fees between the two groups only for the bond fund category. Even worse, bond funds charging incentive fees are significantly more expensive than similar funds with no equivalent performance pay.

Should the performance fee serve as a strategic pricing tool used by managers to increase their profitability, we may expect its occurrence to depend on the ownership structure of the investment companies. The companies owned by a consortium of mutual banks should show the lowest propensity to offer funds with performance fees since they lack a strong drive toward profit maximization. Conversely, should the performance fee be the optimal economic solution to a contracting problem or to a selection problem, the ownership structure of the investment company would play no role in the decision to adopt such a provision.

The evidence from the Italian market fits the managerial perspective better than the economic perspective. Investment companies owned by mutual banks charge performance fees in only $25 \%$ of the funds they manage. This percentage reaches almost $90 \%$ among investment companies labeled as independent and hovers around 70\% among those that belong to banks and insurance groups. Independent investment companies charge incentive fees in most of the funds they manage regardless of their investment objective, while investment companies owned by banks and insurance companies do so only in a minority of bond funds and in a tiny fraction of money market funds.

\section{Logistic Models for Incentive Fee Provisions}


To investigate further how evidence from the Italian market fits with different hypotheses regarding the rationale for incentive fees, we develop five logistic models. In each of them, the dependent variable is set equal to one if the fund charges a performance fee and to zero otherwise.

These models encompass a list of 21 potential explanatory variables suggested either by the managerial perspective of strategic pricing behavior or by the economic perspective of efficient contracting and optimal signaling. From the managerial perspective, the list of relevant variables is as follows.

The size of the fund, LOG(SIZE), as measured by the natural log of its assets is a variable to be considered. Being a proxy of how well established the fund is, it may be a measure of the pricing power the fund enjoys. As such, it could increase the probability that funds charge incentive fees without cutting their management fees. It is also possible, however, to claim the opposite; that a larger fund size may allow a more favorable pricing of asset management services thanks to economies of scale.

The size of the investment company, as measured by the logarithm of its AUM, is LOG(IC_SIZE). Two concurrent factors may be at work here. First, being a proxy of either the market power or the economies of scale that the investment company enjoys, LOG(IC_SIZE) may be the object of the same conflicting claims applicable to the fund size variable. Secondly, since larger investment companies manage a larger number of funds, they can expect to earn a more stable stream of total revenue from performance fees due to a diversification effect. Thus, they unequivocally find this type of reward more appealing than small investment companies do.

Another relevant variable is the fees the investment company pays to its distribution channels normalized with respect to its total AUM. We consider both the fees rewarding the placement of new fund shares (SALES_FEE) and the fees paid annually for securing the 
preservation of a good relationship with current clients, labeled as maintenance fees

(MAINT_FEES). The higher these costs, the higher should be the incentive for risk-averse managers to shift their compensation away from the greater uncertainty of the performance fee and toward the relatively more stable management fee. To account for the possibility that distribution costs are directly charged to investors through loads, the variable SALES_FEE is defined as the gross expense the investment company pays for distribution services minus the loads it earns. We further control for the presence of loads by adding as an explanatory variable a dummy (D_LOAD) equal to one for load funds and equal to zero for no loads. ${ }^{7}$ In theory, we should expect load funds to show a higher propensity to rely on performance fees when compared with no loads since their distribution costs are, at least in part, directly paid by the investors.

The ownership structure of the investment company as measured by a series of dummy variables, D_INS, D_IND, and D_CONS, assuming a value of one whenever the company is part of an insurance group, is independent, or belongs to a consortium of mutual banks is another important variable. The default case, then, relates to investment companies belonging to banking groups. Since the stronger the profit motive, the higher the probability of finding performance fees, we expect a negative coefficient for the variable D_CONS because of the mutual ultimate ownership and a positive coefficient for the variable D_IND, the asset management being the only core business activity of an independent investment company. We would also expect a positive coefficient for D_IND should a scale factor be at work. Independent investment companies lack the extensive proprietary distribution networks

\footnotetext{
${ }^{7}$ Reading the prospectuses, we learn that $51.7 \%$ of the funds in our sample charge a front load and $17.7 \%$ a deferred load. Since these two groups of funds partially overlap, load funds account for $58.8 \%$ of the population. Most of them belong to the equity or total return category. Nonetheless, loads do not appear to be an economically important mechanism to make investors bear the distribution costs of fund shares. For the whole industry, revenue raised from loads is just $8.1 \%$ of the expenses paid to the distribution network for placing fund shares. Almost half of the funds with a deferred load offer partial or full load waivers depending on the length of the stay in the fund. Most of the funds charging a front load offer either partial or full load waivers should the size of the subscription exceed a stated amount.
} 
that their competitors belonging to large banking and insurance companies can count on.

Hence, they need to leverage more on performance fees and less on management fees to profit from successful performances. Since there is no a priori reason to expect any difference in the strategic pricing behavior of investment companies belonging to insurance and banking groups, we expect the coefficient of D_INS will not be statistically significant.

Additionally, the investors' sentiment towards the equity markets at the launch of the fund should be considered. Two opposite, but not mutually exclusive, scenarios are possible. On the one hand, we may expect incentive provisions to become more common after a strong stock market rally. Managers find it easier to increase the price of their service by charging performance fees on top of standard management fees. Investors are enticed to subscribe fund shares by a more immediate perception of a potentially hefty return. Alternatively, managers may rely more on incentive provisions as a form of revenue sharing to entice investors into the funds in a more risk-averse and cost conscious environment ensuing a market bust. ${ }^{8}$ To account for both possibilities, we introduce two dummy variables. D_POS, meant to capture a positive market sentiment, is set equal to one whenever the return on the stock market relevant to the fund investment policy in the twelve months up to its start date is at least $20 \%$. D_NEG, meant to capture a negative market sentiment, is set equal to one whenever this return is negative. ${ }^{9}$ A positive and significant coefficient of D_POS and D_NEG would lend credibility, respectively, to the first and second scenarios described.

The one variable to be considered according to a purely economic perspective is the ability of the manager with respect to his peers, as measured by the standardized fund's performance realized over a two-year period (January 2005-December 2006) as defined by

\footnotetext{
${ }^{8}$ Some of the managers we interviewed pointed out the first scenario. One of the referees suggested the second. ${ }^{9}$ We measure stock market returns using the MSCI Standard Indices. For equity funds with a geographical focus, we use the MSCI Index for that area/country. For funds with no geographical specification of their investment (sector equity funds, hybrid funds and total return funds), we use the MSCI World Index. Results for the estimated coefficients for these variables are robust to a weakening of the threshold to $+15 \%$ for D_POS and $+3 \%$ for D_NEG.
} 
the ratio between the annualized monthly return and standard deviation (REWARD/RISK). The standardized measure is obtained as:

$$
S R R_{i}=\frac{R R_{i}-A R R}{\sigma_{R R}}
$$

where $R R_{i}$ is the reward/risk ratio for fund $i, A R R$ is the average reward/risk ratio for all funds sharing the same investment objective, and $\sigma_{R R}$ is the standard deviation of the reward/risk ratio considered across all funds. Should the incentive fee serve as a valid signal for good managers, we would expect funds with incentive fee provisions in 2004 to show, on average, a superior ability over the following two-year period.

Another variable to be considered purely from an economic perspective is the fund's investment objective as detected by a list of dummy variables taking a value of one if it is equity industry specific (D_INDSP), foreign equity geographically targeted (D_GEO), total return (D_TRET), hybrid (D_HYB), corporate bonds (D_CORP), total return bonds only (D_TRETBOND), specialty bonds only (D_OTHBOND), long-term treasury bonds in euro (D_MLTB), short-term treasury bonds in euro (D_STSTB), or money market (D_MMF). The default case relates to equity funds investing in the Italian market. Should performance fees arise from efficient contracting, the probability of their occurrence should fall as we move down the previously mentioned list of types of funds due to the higher cross-correlation existing among the assets included in their investable universe.

Each logistic model is meant to test a different competing hypothesis, or combination thereof, on the rationale for performance fees. Model 1 tests the signaling hypothesis including as the explanatory variable the reward-to-risk ratio. Model 2 is based on the contracting hypothesis encompassing all the dummy variables stating the investment 
objective of the funds. Model 3 provides a unified view of the economic perspective on the rationale for performance fees, combining Models 1 and 2. Model 4 is derived from the managerial perspective of strategic pricing. Its explanatory variables are LOG(SIZE), LOG(IC_SIZE), SALES_FEE, MAINT_FEE, D_LOADS, the dummies related to the ownership structure of the investment companies (D_INS, D_CONS, and D_IND), as well as those related to the market conditions at the time the funds were established (D_POS and D_NEG). Model 5 includes all twenty-one explanatory variables, the complete list of which is shown in Table IV, Panel A.

Insert Table IV about here.

Due to missing values for some of these variables, the size of the sample used to run the logistic models decreases from 970 to 882 funds, with a corresponding coverage ratio of 91\%. The variable with the most missing data is REWARD/RISK. Because of mergers, of the 970 funds active at the end of 2004, 39 disappeared over the following two years.

In estimating our models, we should also consider that the funds in our sample are managed by 51 investment companies with an average of 19 funds per company. It is reasonable to assume that funds managed by the same company may form a cluster sharing some similarities not captured by our models. The presence of unexplained intra-cluster correlation does not bias the estimates, but may overstate the significance of the coefficients. To control for this effect, we estimate our models allowing for intra-cluster correlation (between the residuals and the explanatory variables) while assuming zero correlation among clusters (Wooldridge, 2002).

\section{The Whys of Incentive Provisions}


Table V provides the results for each logistic model, as well as for an OLS regression model in which the management fee is determined as a function of the same set of independent variables.

Insert Table V about here.

The results from Model 1 do not provide significant support for the role of incentive fee provisions as a signaling device for managers' abilities. Its explanatory power is negligible as it has a Nagerlarke pseudo $\mathrm{R}^{2}$ less than $1 \% .^{10}$ There is no significant relation between the adoption of a pay for performance compensation scheme and the subsequent funds' riskadjusted performance. Despite the poor results of this model, the possibility that an incentive fee may serve as a signal cannot be completely ruled out. In theory, a signaling equilibrium would still be possible with good managers separating themselves from bad managers through reward schemes with a stronger bias in favor of the incentive fee at the expense of the management fee.

Model 2 is related to the efficient contracting hypothesis. It demonstrates a better explanatory power with a Nagerlake pseudo $\mathrm{R}^{2}$ equal to $17.7 \%$. The estimated coefficients follow the expected pattern. As we move from funds investing in an asset class of securities with low cross-correlation (equity and total return funds) to funds whose purchasable assets are more cross-correlated (starting from total return bond, corporate bond, hybrid, medium and longterm treasury bond funds, and ending up with short-term treasury bonds and money market funds), the tendency to use incentive fees strongly decays.

As revealed by the last column of Table $\mathrm{V}$, a similar pecking order is found in terms of the impact these variables have on the management fee. Thus, the pricing of the asset

\footnotetext{
${ }^{10}$ As the $\mathrm{R}^{2}$ of the standard OLS regression, the Nagerlake pseudo $\mathrm{R}^{2}$ of a logistic model ranges from $0-1$.
} 
management service is set in a way to closely mirror the potential added value that the asset managers may generate for the investors. In this respect, of the two components of the asset management service, stock picking appears to be valued more than market timing. All types of equity funds carry, on average, a higher management fee than hybrid and total return funds do, while showing a probability at least as high to charge performance fees. Moreover, in the equity category, the ability to manage both sector-specific and foreign-targeted funds appears to be more valuable than the ability to invest in Italian stocks since they command a statistically significantly higher reward in terms of management fees with no differences in the probability of charging performance fees.

Model 3 combines Models 1 and 2 to assess the overall explanatory power of interpreting performance fee schemes as an economically efficient solution in a fully rational asset management industry plagued by asymmetric information. All results are confirmed and Model 3 has no gain in terms of explanatory power with respect to Model 2.

Model 4 provides a test for the strategic pricing hypothesis derived under a managerial perspective. The improvement in explanatory power is remarkable. The Nagerlake pseudo $\mathrm{R}^{2}$ climbs to $31.2 \%$ and the pattern of estimated coefficients is as expected. The novel managerial approach we propose appears to be superior to the traditional economic efficiency approach in explaining the decision to rely on incentive fees to reward fund managers.

The higher the cost of the distribution channel for an investment company in terms of both sales fees (net of earned loads) and maintenance fees, the lower the probability that its funds carry an incentive provision. At the same time we observe an increase in the size of the management fee, and both results are significant at the 5\% level. When facing a more burdensome cost structure, risk-averse managers demonstrate a desire to lower the uncertainty of their income structure, foregoing the possibility of earning more volatile 
performance fees in exchange for a higher and more stable stream of management fees. If so, in theory, we should also expect load funds to show a higher propensity to rely on performance fees when compared with no loads since distribution costs are, at least partially, directly paid for by the investors. We find a result that apparently supports this argument, even if at a low level of statistical significance (10\%). The result is surprising, however, given the marginal economic relevance of loads in the Italian fund market. In order to solve this contradiction we have to consider that Model 4 does not control for fund categories and so a spurious correlation may be at work here since both incentive provisions and loads are more common among equity and total return funds.

Larger investment companies appear to exploit their market power by showing a significantly higher propensity to charge incentive fees than do smaller ones without significantly decreasing the level of their management fee as shown in the last column of Table V. This evidence also fits well with the claim that larger companies are more willing to base part of their compensation on incentive provisions due to the stronger diversification effect they enjoy by managing a larger number of funds. The market power hypothesis does not find similar support at the fund level. The size of the fund is not related to the probability of finding an incentive provision in the manager's compensation scheme, nor does it show any significant effect on the level of management fee.

The ownership structure of the investment companies is also highly statistically significant in determining the pricing of the asset management services. Investment companies that are part of an insurance group do not significantly differ from those belonging to banking groups when setting both performance and management fees for their funds. As expected, the companies co-owned by several less profit oriented mutual banks show a significantly lower propensity to adopt incentive fees. They also charge management fees that, on average, are appreciably lower by about fourteen basis points as compared with those 
charged by asset managers belonging to banking and insurance groups. At the other end of the spectrum, independent investment companies combine a higher proclivity to set performance fee provisions with a softer stance on the level of management fees. For their funds, the latter are, on average, twenty basis points lower than those found in funds run by the companies which are part of a banking group.

The combined reading of these two discrepancies suggests that the stronger tendency for independent companies to charge performance fees may depend on the presence of a smaller scale factor in the distribution process rather than on a stronger profit motive. Since they cannot rely on extensive distribution networks, a positive fund performance does not translate into higher capital inflows as easily as it does for companies belonging to insurance or banking groups. Therefore, they find it more convenient to reap the benefit of a positive track record directly through performance fees rather than waiting for a higher income from management fees applied to an expanding asset base.

The investors' sentiment towards the equity market, as driven by the market trend in place at the launch of the fund, significantly affects the probability that a new fund will carry performance fee provisions. Since D_POS is positive and significant at the $1 \%$ level, we find strong support for the hypothesis that investment companies launch funds with performance fees after strong market rallies to take full advantage of investors who are less cost sensitive. They do so without sacrificing any part of the usual management fee as D_POS shows no influence at all on this component of the manager's compensation. The evidence also lends similar support to the opposite, but complementary, scenario depicting incentive provisions as revenue sharing schemes useful to attract very cautious investors following market busts. D_NEG demonstrates an equally positive and strongly significant influence on the introduction of incentive provisions, while it shows a negative, albeit not significant, impact on the level of management fees. 
Model 5 combines the previous two models. All of the explanatory variables contained in Model 4 and derived by the managerial approach maintain their sign and statistical significance with two minor exceptions. As we expected in a model that appropriately controls for fund types, D_LOADS turns out to be an irrelevant factor in setting the reward scheme for Italian fund managers. Alternatively, the size of the funds [LOG(SIZE)] indicates a positive and significant (at the 5\% level) effect on the presence of an incentive provision as suggested by the pricing power hypothesis. Correspondingly, however, the other variable we use as a proxy of the exercise of market power, the size of the investment company [LOG_IC(SIZE)], loses part of its relevance and it is now significant only at the $5 \%$ level instead of at the $1 \%$ level, as it is in Model 4.

In Model 5, the fund category attribution sees its statistical significance weakened when compared with the results of Model 3 derived from the economic efficiency approach. The tendency to introduce performance fees appears to be similar across all fund categories. The only exception consists of the funds aimed at investing either in money market instruments or in plain medium and long-term government bonds for which the parameters remain significantly negative, denoting a lower probability of detecting an incentive provision.

When combined, the managerial and the economic approaches we investigated are, to some extent, complementary as indicated by the pseudo $\mathrm{R}^{2}$ reaching in Model 5 a value of 0.41. The results of Model 5, however, leave no doubt that performance provisions in mutual funds arise more as the product of a strategic pricing policy pursued by the managers promoting the funds than as an optimal response to both an efficient contracting problem and a signaling problem in an imperfect information setting.

The analysis conducted so far encompasses all categories of mutual funds and relies on a series of dummy variables to capture any category attribution effect. Nonetheless, this 
mixing of fund categories may cloud the results. Some of the explanatory variables we employ are correlated with fund categories and some categories have far fewer incentive provisions than others. So, to some extent, there is the risk that some of the effects we detect are just picking up fund categories.

To verify the robustness of our results, we test similar logistic models only on our subsample of 381 equity funds. To control for the large variety of their investment mandate, we introduce a series of dummy variables with self-explanatory names aimed to capture any effects resulting from the attribution of each fund to a different Assogestioni equity subcategory. They are detailed in Table IV, Panel B. The default case still relates to equity funds investing only in the Italian stock market.

The results, illustrated in Table VI, provide a full validation of the empirical evidence revealed by looking at our full sample of funds.

Insert Table VI about here.

The managerial approach entirely maintains its explanatory power. The economic approach appears to be even more inadequate to explain the adoption of incentive provisions due to the persistent failure of the signaling hypothesis and the difference among equity fund subcategories appears to be not meaningful enough from an efficient contracting perspective. In fact, the dummy variables related to the equity fund subcategories are largely insignificant in explaining the adoption of incentive provisions.

By comparing the last column of Tables V and VI, we also find confirmation of the significant effects on the size of the management fee carried by the cost and ownership structure of the investment companies we already detected for the whole sample of funds. 
The results in Table VI also reveal that equity funds targeting a specific sector command a higher management fee, on average, than equity funds with a geographical target.

\section{The Effects of Incentive Fees}

Previous theoretical studies warn about the moral hazard risk performance provisions may generate. Because of this danger, policymakers in the U.S. outlawed bonus plans in 1970, making the adoption of a performance fee an extremely unusual form of reward for asset managers (Golec and Starks, 2004). Lacking the data, however, to the best of our knowledge, there are no other empirical investigations concerning opportunistic behavior induced by asymmetric performance fees actually taking place. The evidence regarding the Italian market can help to fill this void. We confine our analysis to the subsample of equity funds as they are the ones most exposed to the risk of moral hazard.

Asset managers may indulge in three types of opportunistic behavior due to a reward scheme based on an asymmetric performance fee: 1) they may increase the risk of the fund, especially if no appropriate correction for it is adopted in calculating the incentive fee as happens in the Italian mutual fund industry that we analyze (standard asset substitution risk); 2) they may manage a portfolio of funds with identical investment objectives taking care to minimize their funds' correlations to stabilize their income from performance fees (portfolio asset substitution risk); or 3) they may alter, according to the fund's realized performance, the risk profile of the fund when approaching the end of the incentive fee calculation period (dynamic asset substitution risk).

To test for the possibility that asset managers react to an asymmetric performance fee scheme that provides no correction for risk by selecting excessively aggressive investment strategies, we run a linear model whose dependent variable is the annualized monthly standard deviation of the funds' returns from January 2005-December 2006. The explanatory 
variables consist of a dummy (D_INC FEE) set equal to one if the fund charges an incentive fee, the management fee (MAN FEE), plus a list of additional variables defined in the previous section and designed to control for the size of the investment company [LOG(IC_SIZE)], for the ownership structure of the investment company (D_INS, D_CONS, and D_IND) and for the subcategories employed by Assogestioni to partition the equity funds with respect to their specific investment objectives.

The same linear model is also run for funds' returns and for funds' reward-to-risk ratio to provide a more complete assessment of the effect of the manager's reward scheme. As Table VII indicates, when earning incentive fees, managers increase fund volatility adding, on average, 2.6 percentage points to their annualized standard deviation. This effect, however, fails to be significant at the usual levels (p-value of 0.18 ). The incentive fee provision is even less significantly related to the funds' average rate of return. Its positive effect of $0.6 \%$ per year suggested by the point estimate confirms a p-value of 0.676 .

Insert Table VII about here.

On the whole, while limited to a very narrow time frame (two years of data from January 2005-December 2006), but extending to almost 400 equity funds, the evidence suggests that incentive provisions have no effect on the welfare of the investors. As shown in the third column of Table VII, the negative point estimate for the variable Reward-to-Risk Ratio fails to reach significance once all other relevant variables have been controlled for.

The size of the management fee is equally lacking a statistically significant explanatory power on both funds' risk and funds' return. Contrary to incentive provisions, however, the point estimates suggest higher management fees are associated with an increase in the funds' standard deviation and a decrease in the funds' average returns. Since they are 
both welfare decreasing effects from the investor's perspective, the negative impact of the management fee size on the reward-to-risk ratio equity funds deliver successfully passes the test of statistical significance (p-value of 0.002 ).

We now turn to the risk that an investment company may exploit opportunistically asymmetric performance fee provisions offering several funds with a similar risk/return profile and a similar investment universe, while managing them in such a way as to minimize the correlation in their rate of return. The risk arises because of the asymmetric nature of the bonus plan. By diversifying portfolio choices among comparable funds, managers may stabilize their incentive fee stream of income, cashing in fees from the successful funds while incurring no financial loss from the others.

To assess how material the portfolio asset substitution risk is, we measure the average correlation between funds that share the same investment objective, charge an incentive fee, and are managed by the same investment company. We then compare this correlation with the average correlation of random groups of funds with the same investment objective available to investors.

Despite being theoretically relevant, this moral hazard risk does not materialize in our sample, as Table VIII indicates. Across the 12 different categories of equity funds considered and the 51 investment companies operating in Italy, in just one case (one investment company managing a group of six different European equity funds) the average correlation among funds with bonus plans, similar investment objectives, and run by the same company demonstrates a correlation significantly lower than that which appears to be standard for that fund category (0.887 against 0.938 with the difference significant at the $5 \%$ level). In all other instances, this difference is either not significant or it appears to be significant, but in the opposite direction. If anything, investment companies tend to replicate the same 
investment strategies on all similar funds with incentive provisions that they manage; exactly the opposite of what was feared.

\section{Insert Table VIII About Here.}

There are also fears that, while approaching the fee calculation date, the manager may shift a fund's risk profile according to the fund performance accrued until then during the fee calculation period. To test how material this risk is in the real world, in the spirit of Brown, Harlow, and Starks (1996), we consider the equity funds that charge an annual synchronous incentive fee on the spread between their returns and a reference portfolio, either their benchmark or an index of mutual funds returns. We estimate the spread volatility over different time windows, the $x$ trading days preceding and following the calculation date, with $x=20,40,60$ days. We then calculate the ratio between the spread volatility over a period of identical length prior to and following each calculation date. Brown et al. (1996) labeled this metric "risk adjustment ratio". Ratios greater (smaller) than one mean that the fund runs a higher (lower) spread volatility toward the end of its current calculation period than it does at the start of the next one.

For each fund and each calculation period, we track the cumulated absolute active return from the corresponding start date. Funds with lower absolute active returns $\left(\left|R_{p}-R_{B}\right|\right)$ are "close to the benchmark". They offer their asset manager a strong incentive to increase the spread volatility when approaching the calculation date. The option embedded in the performance fee is almost "at the money", carrying a very high vega. Since after each calculation date, a fresh start in determining the new incentive fee occurs, we expect to find a higher risk adjustment ratio in funds which are close to the benchmark and carry a high vega when nearing the calculation date. 
To test the relation between the vega of the option implied in a performance fee provision and the possibility of an opportunistic risk shift when approaching the end of the calculation period, we build a two-by-two table in which funds are divided according to their absolute cumulative active return since the start date and the size of the risk adjustment ratio around the final calculation date. Since we use the median values of the two distributions as cutting points, should asset managers refrain from any opportunistic behavior, the null hypothesis of independence between the two variables would hold and the observations would spread evenly ( $25 \%$ frequency) in every cell of the table. Conversely, if the asset managers act opportunistically, we would expect the observations to cluster in two of the four cells of the table: 1) close to the benchmark - high risk adjustment ratio and 2) far from the benchmark - low risk adjustment ratio. We also perform a similar analysis replacing the spread volatility with the reciprocal of the correlation between a fund and its hurdle variable as the measure of risk.

Regardless of the risk metrics used, the results shown in Table IX do not support the theoretical claim that the vega of the option embedded in the performance fee generates a dynamic asset substitution effect. In both cases, the chi-square test on the two-way table does not reject the null hypothesis of the absence of any opportunistic behavior. If anything, on the shorter assessment period considered of just twenty days, inspection of the two-by-two table suggests that funds nearing the calculation date with a high vega tend to end the calculation period with a lower risk than the one they bear at the beginning of the next calculation period. The clustering of the observations, however, is not such as to generate statistically significant results.

Insert Table IX About Here. 


\section{Summary and Conclusions}

Thanks to the experience of Italy, a country where until 2006 there was only one minor regulatory constraint on the permissible structure of the reward scheme for mutual fund managers, we are able to test some relevant hypotheses on the determinants and effects of pay-for-performance arrangements in the mutual fund industry. Such a free contracting environment is in stark contrast with the experience of the U.S. where an invasive regulation, permitting only fulcrum fee provisions, has driven almost all managers toward compensation schemes based exclusively on management fees.

In a free contracting environment, performance provisions are a typical element of the pay package of mutual fund managers always in the form of a bonus plan. There are, however, huge differences in their rate of utilization across different categories of mutual funds. While these provisions are industry standard for both equity and total return funds, they are a rarity among money market funds. Bonds and hybrid funds stand in-between.

There is no evidence supporting the hypothesis that incentive fee provisions serve as a signaling tool that good investment managers use to separate themselves from bad ones. They do not appear to be a costly device for the equity and total return managers making them ineffective as a signal of investment ability.

The evidence is more supportive of the role of incentive provision as a device for optimal contracting aimed at disciplining the moral hazard risk arising from managers whose effort is unobservable. From this perspective, however, the choice of some funds to compute the performance fee on their return in excess of hurdle variables that carry no relation at all to their investment mandate is questionable and puzzling.

Performance provisions appear to emerge mostly as the product of strategic pricing policies pursued by the investment companies. They are more common among funds managed by companies driven by a strong profit motive, as well as among those who cannot 
leverage the benefit of their positive performance through an extensive distribution network to gain massive new inflows of funds. They are also more common among funds launched during strong and sustained stock market rallies, which probably make retail investors less concerned about the cost structure of the asset management services. Smaller asset managers, as well as those bearing the burden of more expensive distribution channels, are less keen on performance fee provisions. Because of their risk aversion, they prefer to rely on the more stable flow guaranteed by the management fee.

We find no significant evidence that asset managers, responding opportunistically to the incentive provided for by the fee provision, pursue inappropriate investment policies designed to optimize their revenue stream rather than their funds' risk/return profile. Funds with incentive provision demonstrate higher risk and higher return than do comparable funds without it, but neither result passes the test of statistical significance. There is also no evidence that managers rewarded with a bonus plan purposely diversify the investment strategies of their funds with similar mandates to stabilize the flow of their performance fees. The same can be said with respect to the risk that opportunistic managers may adjust the riskreturn profile of their funds when approaching the performance fee calculation date either to lower the risk and lock in the realized out performance or to increase the risk hoping to recover the realized under performance before the calculation period ends. The risk of losing their reputational capital and of seeing their AUM shrink appears to make investment companies aware that their payoff is not as asymmetrical as it would seem should we focus just on the incentive provision. 


\section{References}

Admati, A. and P. Pfeiderer, 1997, "Does It All Add Up? Benchmarks and the Compensation of Active Portfolio Managers," Journal of Business 70(3), 323-350.

Assogestioni, 2004, Factbook 2004, Milan.

Assogestioni, 2005, Factbook 2005, Milan.

Blitz, D. and A. Hottinga, 2001, "Tracking Error Allocation," The Journal of Portfolio Management 27(4), 19-26.

Brown, K., V. Harlow, and L. Starks, 1996, "Of Tournaments and Temptations: An Analysis of Managerial Incentives in the Mutual Fund Industry," Journal of Finance 51(1), 85110.

Carpenter, J., 2000, "Does Option Compensation Increase Managerial Risk Appetite?" The Journal of Finance 55(5), 2,311-2331.

Chevalier, J. and G. Ellison, 1997, "Risk Taking by Mutual Funds as a Response to Incentives," Journal of Political Economy, 105(6), 1,167-1,200.

Chevalier, J. and G. Ellison, 1999, "Career Concerns of Mutual Funds Managers," Quarterly Journal of Economics 114(2), 389-432.

Cohen, S. and L. Starks, 1988, "Estimation Risk and Incentive Contracts for Portfolio Managers," Management Science 34(9), 1,067-1,079.

Cuoco, D. and R. Kaniel, 2000, "General Equilibrium Implications of Fund Managers' Compensation Fees," Working Paper.

Das, S. and R. Sundaram, 2002, "Fee Speech: Signaling, Risk-Sharing and the Impact of Fee Structures on Investor Welfare," Review of Financial Studies 15(5), 1,465-1,497.

Drago, D., V. Lazzari, and M. Navone, 2008, "The Real Cost of Asymmetric Incentive Fees," Working Paper.

Elton, E., M. Gruber, and C. Blake, 2003, "Incentive Fees and Mutual Funds," Journal of Finance 58(2), 779-804.

Evans, A., 2008, "Portfolio Manager Ownership and Mutual Fund Performance," Financial Management 37(3), 513-534.

Gaver, J. and K. Gaver, 1995, "Compensation Policy and the Investment Opportunity Set," Financial Management 24(1), 19-32.

Golec, J. and L. Starks, 2004, "Performance Fee Contract Change and Mutual Fund Risk," Journal of Financial Economics 73(1), 93-118.

Goodwin, T., 1998, "The Information Ratio," Financial Analysts Journal 54(4), 34-43. 
Goriaev A., F. Palomino, and A. Prat, 2000, "Mutual Fund Tournament: Risk Taking Incentives Induced by Ranking Objectives," Centre for Economic Research Working Paper Series, London School of Economics, 2000-94.

Gupta, F., R. Prajogi, and E. Stubbs, 1999, "The Information Ratio and Performance," The Journal of Portfolio Management 26(1), 33-39.

Holmstrom, B., 1979, "Moral Hazard and Observability," The Bell Journal of Economics 10(1), 74-91.

Sirri, E. and P. Tufano, 1998, "Costly Search and Mutual Funds Flows," The Journal of Finance 53(5), 1,589-1,622.

Spence, M., 1973, "Job Market Signaling," Quarterly Journal of Economics 87(3), 355-374.

Starks, L., 1987, "Performance Incentive Fees: An Agency Theoretic Approach," Journal of Financial and Quantitative Analysis 22(1), 17-32.

Stremme, A., 1999," Optimal Compensation for Fund Managers of Uncertain Type: Informational Advantages of Bonus Scheme," Stern School of Business, New York University Working Paper.

Wooldridge, J., 2002, Econometric Analysis of Cross Section and Panel Data, Cambridge, MA, MIT Press. 
Table I. The Italian Mutual Fund Industry

The table illustrates the structure of the Italian mutual fund industry as at the end of 2004 (Assogestioni, 2004).

\begin{tabular}{|c|c|c|c|c|c|c|c|c|}
\hline \multicolumn{9}{|c|}{ Panel A: Industry Breakdown for Number of Funds } \\
\hline \multirow{2}{*}{$\begin{array}{l}\text { Investment } \\
\text { Company }\end{array}$} & \multirow{2}{*}{$\begin{array}{l}\text { No. of Inv. } \\
\text { Companies }\end{array}$} & \multicolumn{5}{|c|}{ Percentage of Managed Funds of Different Type } & \multicolumn{2}{|c|}{$\begin{array}{c}\text { Total Number } \\
\text { of Funds }\end{array}$} \\
\hline & & Equity & Hybrid & $\begin{array}{l}\text { Tot. } \\
\text { Ret. }\end{array}$ & Money & Bonds & Number & $\%$ \\
\hline Insurance & 4 & $50.9 \%$ & $6.5 \%$ & $8.3 \%$ & $3.7 \%$ & $30.6 \%$ & 108 & $11.1 \%$ \\
\hline Commercial Banks & 29 & $41.5 \%$ & $10.4 \%$ & $6.1 \%$ & $4.5 \%$ & $37.5 \%$ & 661 & $68.1 \%$ \\
\hline Cooperative Banks & 2 & $47.7 \%$ & $6.8 \%$ & $2.3 \%$ & $6.8 \%$ & $36.4 \%$ & 44 & $4.5 \%$ \\
\hline Independent & 16 & $45.2 \%$ & $4.4 \%$ & $13.4 \%$ & $4.5 \%$ & $32.5 \%$ & 157 & $16.2 \%$ \\
\hline Total Sample & 51 & $43.4 \%$ & $8.9 \%$ & $7.3 \%$ & $4.5 \%$ & $35.9 \%$ & 970 & $100.0 \%$ \\
\hline \multicolumn{9}{|c|}{ Panel B: Industry Breakdown for Assets Under Management (AUM) } \\
\hline \multirow{2}{*}{$\begin{array}{l}\text { Investment } \\
\text { Company }\end{array}$} & \multirow[b]{2}{*}{ Companies } & \multicolumn{5}{|c|}{ AUM for Type of Funds } & \multicolumn{2}{|c|}{ Total AUM } \\
\hline & & Equity & Hybrid & $\begin{array}{l}\text { Tot. } \\
\text { Ret. }\end{array}$ & Money & Bonds & $€-$ Millions & $\%$ \\
\hline Insurance & 4 & $33.1 \%$ & $6.4 \%$ & $3.6 \%$ & $3.0 \%$ & $53.9 \%$ & $18,498.32$ & $5.2 \%$ \\
\hline Commercial Banks & 29 & $17.7 \%$ & $8.0 \%$ & $1.7 \%$ & $24.3 \%$ & $48.3 \%$ & $292,273.02$ & $81.8 \%$ \\
\hline Cooperative Banks & 2 & $21.9 \%$ & $15.2 \%$ & $0.3 \%$ & $25.6 \%$ & $37.0 \%$ & $27,575.28$ & $7.7 \%$ \\
\hline Independent & 16 & $25.9 \%$ & $11.9 \%$ & $19.7 \%$ & $15.5 \%$ & $27.0 \%$ & $18,908.20$ & $5.3 \%$ \\
\hline Total Sample & 51 & $19.3 \%$ & $8.7 \%$ & $2.6 \%$ & $22.8 \%$ & $46.6 \%$ & $357,254.82$ & $100.0 \%$ \\
\hline \multicolumn{9}{|c|}{ Panel C: Average Management Fee } \\
\hline \multirow{2}{*}{$\begin{array}{c}\text { Investment } \\
\text { Company }\end{array}$} & \multirow{2}{*}{$\begin{array}{l}\text { No. of Inv. } \\
\text { Companies }\end{array}$} & \multicolumn{6}{|c|}{ Average Management Fee for Type of Funds } & \\
\hline & & Equity & Hybrid & $\begin{array}{l}\text { Tot. } \\
\text { Ret. }\end{array}$ & Money & Bonds & $\begin{array}{c}\text { Total } \\
\text { Sample }\end{array}$ & \\
\hline Insurance & 4 & $1.94 \%$ & $1.63 \%$ & $1.44 \%$ & $0.50 \%$ & $1.19 \%$ & $1.60 \%$ & \\
\hline Commercial Banks & 29 & $1.94 \%$ & $1.60 \%$ & $1.63 \%$ & $0.55 \%$ & $1.01 \%$ & $1.47 \%$ & \\
\hline Cooperative Banks & 2 & $1.82 \%$ & $1.43 \%$ & $1.80 \%$ & $0.52 \%$ & $1.00 \%$ & $1.43 \%$ & \\
\hline Independent & 16 & $1.60 \%$ & $1.37 \%$ & $1.51 \%$ & $0.57 \%$ & $0.93 \%$ & $1.31 \%$ & \\
\hline Total Sample & 51 & $1.88 \%$ & $1.58 \%$ & $1.57 \%$ & $0.55 \%$ & $1.02 \%$ & $1.46 \%$ & \\
\hline
\end{tabular}




\section{Table II. Incentive Fees in the Italian Mutual Fund Industry}

The table illustrates to what extent the Italian mutual fund industry was making use of performance fee provisions at the end of 2004. The data on assets under management (AUM) are from Assogestioni (2004). Data on incentive fees were hand collected from the funds' prospectuses.

\begin{tabular}{lcccc}
\hline \hline Fund Category & $\begin{array}{c}\text { Number } \\
\text { of Funds }\end{array}$ & $\begin{array}{c}\text { AUM } \\
\text { (Millions of } € \text { ) }\end{array}$ & \multicolumn{2}{c}{ Funds that Charge Incentive Fees } \\
\hline Equity & & & $\begin{array}{c}\text { As a \% of the } \\
\text { Number of } \\
\text { Funds }\end{array}$ & As a \% of AUM \\
\cline { 3 - 4 } Hybrid & 421 & $68,832.04$ & $82.9 \%$ & $87.4 \%$ \\
Bond & 86 & $31,207.09$ & $67.4 \%$ & $72.0 \%$ \\
Money Market & 348 & $166,353.93$ & $52.6 \%$ & $45.7 \%$ \\
Total Return & 44 & $81,542.89$ & $9.1 \%$ & $3.8 \%$ \\
\hline Total & 71 & $9,318.87$ & $82.9 \%$ & $79.7 \%$ \\
\hline \hline
\end{tabular}


Table III. The Size of Management Fees

The table demonstrates the average size of the management fee across different categories of Italian mutual funds with and without incentive fees. The test of equal means under the assumption of unknown, but equal variance is also reported.

\begin{tabular}{lrrrr}
\hline \hline Fund Category & $\begin{array}{c}\text { Without } \\
\text { Incentive Fee }\end{array}$ & $\begin{array}{c}\text { With Incentive } \\
\text { Fee }\end{array}$ & Full Sample & P-Value \\
\hline Equity Funds & $1.85 \%$ & $1.90 \%$ & $1.89 \%$ & 0.302 \\
Hybrid Funds & $1.51 \%$ & $1.61 \%$ & $1.58 \%$ & 0.261 \\
Bond Funds & $0.97 \%$ & $1.08 \%$ & $1.03 \%$ & 0.002 \\
Money Market Funds & $0.54 \%$ & $0.63 \%$ & $0.55 \%$ & 0.447 \\
Flexible Funds & $1.47 \%$ & $1.60 \%$ & $1.58 \%$ & 0.369 \\
\hline \hline
\end{tabular}


Table IV.Description of the Full Set of Potential Explanatory Variables for Performance Fee Provisions

\begin{tabular}{|c|c|}
\hline Variable & Description \\
\hline \multicolumn{2}{|r|}{ Panel A } \\
\hline REWARD/RISK & $\begin{array}{l}\text { Ratio between the fund return and its standard deviation from January } 2005 \text {-December } 2006 \text { minus the average } \\
\text { ratio of funds with the same investment objective divided by the cross-sectional standard deviation of ratios } \\
\text { within the investment objective. }\end{array}$ \\
\hline LOG(SIZE) & Natural logarithm of the size of the mutual fund. \\
\hline D_MMF & Dummy variable equal to one when the fund is invested in euro-denominated money market instruments. \\
\hline D_STEB & Dummy variable equal to one when the fund is invested in short-term euro-denominated government bonds. \\
\hline D_MLTEB & $\begin{array}{l}\text { Dummy variable equal to one when the fund is invested in medium and long-term euro-denominated } \\
\text { government bonds. }\end{array}$ \\
\hline D_CORP & Dummy variable equal to one when the fund is invested in corporate bonds. \\
\hline D_OTHBOND & Dummy variable equal to one when the fund is a bond fund that does not fit into any other bond category. \\
\hline D_TRETBOND & Dummy variable equal to one when the fund is a total return fund invested in bonds. \\
\hline D_HYB & Dummy variable equal to one when the fund is a hybrid fund. \\
\hline D_GEO & Dummy variable equal to one when the fund is geographically targeted on foreign equities. \\
\hline D_INDSP & Dummy variable equal to one when the fund is equity industry specific. \\
\hline D_TRET & Dummy variable equal to one when the fund is a total return fund. \\
\hline LOG(IC_SIZE) & Natural logarithm of the total asset under management for the investment company that manages the fund. \\
\hline SALES_FEES & $\begin{array}{l}\text { Ratio between the sales fee paid by the investment company to the distribution channel (minus the loads } \\
\text { earned) when new assets are invested in the fund and the total assets are under management of the investment } \\
\text { company. }\end{array}$ \\
\hline MAINT_FEES & $\begin{array}{l}\text { Ratio between the maintenance fees paid by the investment company to the sales channel every year on the } \\
\text { existing AUM and the total assets under management of the investment company. }\end{array}$ \\
\hline D_LOADS & Dummy variable equal to one if the fund charges front- or back-end loads. \\
\hline D_INS & Dummy variable equal to one when the investment company is owned by an insurance company. \\
\hline D_CONS & Dummy variable equal to one when the investment company is owned by a consortium of mutual banks. \\
\hline D_IND & $\begin{array}{l}\text { Dummy variable equal to one when the investment company is independent or is not owned by a subject with a } \\
\text { proprietary distribution channel in Italy. }\end{array}$ \\
\hline
\end{tabular}


Table IV.Description of the Full Set of Potential Explanatory Variables for Performance Fee Provisions (Continued)

\section{Variable}

DPOS

D_NEG

\section{Description}

Dummy variable equal to one for equity, hybrid or total return funds when the return of the market in which they are invested has been, in the year prior to the creation of the fund, higher than $20 \%$.

Dummy variable equal to one for equity, hybrid, or total return funds when the return of the market in which they are invested has been, in the year prior to the creation of the fund, lower than $-20 \%$.

\begin{tabular}{ll}
\hline \multicolumn{1}{c}{ Panel B: Dummy Variables Representing Assogestioni Classification of the Fund in an Equity Subcategory } \\
\hline D_Euro Zone & $=1$ if the fund is invested in Euro Zone equities. \\
D_European Eq. & $=1$ if the fund is invested in European equities. \\
D_USA Eq. & $=1$ if the fund is invested in U.S. equities. \\
D_Pacific Eq. & $=1$ if the fund is invested in Pacific area equities. \\
D_Emerging Markets & $=1$ if the fund is invested in emerging market equities. \\
D_International Eq. & $=1$ if the fund is invested in international equities. \\
D_Country Specific & $=1$ if the fund is targeting stocks listed in a specific country. \\
D_Consumer Goods & $=1$ if the fund is invested in consumer goods stocks. \\
D_Energy & $=1$ if the fund is invested in energy stocks. \\
D_Finance & $=1$ if the fund is invested in stocks of financial corporations. \\
D_Health Care & $=1$ if the fund is invested in health care stocks. \\
D_Information Tech. & $=1$ if the fund is invested in IT stocks. \\
D_Telecom. Services & $=1$ if the fund is invested in telecom service stocks. \\
D_Other Industries & $=1$ if the fund belongs to a remaining industry-specific category. \\
D_Other & $=1$ if none of the above applies and the fund is not targeting the Italian stock market (default case).
\end{tabular}


Table V. The Causes of Performance Fee Provisions

The results of five logistic models that aspire to explain performance fee provisions are shown below. The independent variables are described in Panel A of Table IV. The last column indicates the results of an OLS model intended to explain the management fee using the same set of variables. Data on funds' characteristics at the end of 2004 are from Assogestioni (2004). Standard Errors have been estimated by clustering the observations within investment companies. Significance at the $1 \%, 5 \%, 10 \%$ levels is marked by $* * *, * * *$, respectively. Since 88 funds out of a population of 970 show data missing for at least one of the variables considered, models are run on a reduced sample of 882 funds. t-stats in parenthesis.

\begin{tabular}{|c|c|c|c|c|c|c|}
\hline & $\begin{array}{c}\text { Model } 1 \\
\text { (Signaling) }\end{array}$ & $\begin{array}{l}\text { Model } 2 \\
\text { (Optimal } \\
\text { Contract) }\end{array}$ & $\begin{array}{c}\text { Model } 3 \\
\text { M1+M2 }\end{array}$ & $\begin{array}{c}\text { Model } 4 \\
\text { (Strategic } \\
\text { Pricing) } \\
\end{array}$ & $\begin{array}{l}\text { Model } 5 \\
\text { (Global) }\end{array}$ & $\begin{array}{c}\text { Management } \\
\text { Fee }\end{array}$ \\
\hline \multirow[t]{2}{*}{ Constant } & 0.824 & 1.695 & 1.707 & -2.403 & -1.676 & 1.778 \\
\hline & $(3.306)^{* * *}$ & $(3.647)^{* * *}$ & $(3.612)^{* * *}$ & (1.545) & $(0.952)$ & $(10.935)^{* * *}$ \\
\hline \multirow[t]{2}{*}{ REWARD/RISK } & -0.142 & & -0.092 & & -0.261 & -0.044 \\
\hline & $(1.464)$ & & $(0.848)$ & & $(2.477)^{* *}$ & $(3.028)^{* * *}$ \\
\hline \multirow[t]{2}{*}{ D_MMF } & & -3.369 & -3.315 & & -3.835 & -1.146 \\
\hline & & $(6.252)^{* * *}$ & $(6.356) * * *$ & & $(6.734)^{* * *}$ & $(20.219) * * *$ \\
\hline \multirow[t]{2}{*}{ D_STEB } & & -2.076 & -2.085 & & -2.186 & -1.009 \\
\hline & & $(4.236)^{* * *}$ & $(4.198)^{* * * *}$ & & $(4.471)^{* * * *}$ & $(19.433)^{* * *}$ \\
\hline \multirow[t]{2}{*}{ D_MLTEB } & & -1.289 & -1.329 & & -1.206 & -0.742 \\
\hline & & $(2.838)^{* * *}$ & $(2.829)^{* * *}$ & & $(2.358)^{* *}$ & $(18.020) * * *$ \\
\hline \multirow[t]{2}{*}{ D_CORP } & & -1.346 & -1.363 & & -0.900 & -0.581 \\
\hline & & $(2.455)^{* *}$ & $(2.465)^{* *}$ & & $(1.521)$ & $(10.655)^{* * *}$ \\
\hline \multirow[t]{2}{*}{ D_OTHBOND } & & -1.135 & -1.170 & & -0.878 & -0.608 \\
\hline & & $(1.968)^{* *}$ & $(1.986)^{* *}$ & & (1.387) & $(11.384) * * *$ \\
\hline \multirow[t]{2}{*}{ D_TRETBOND } & & -0.972 & -0.982 & & -0.592 & -0.681 \\
\hline & & $(2.184)^{* *}$ & $(2.167)^{* *}$ & & (1.212) & $(20.500)^{* * *}$ \\
\hline \multirow[t]{2}{*}{ D_HYB } & & -0.982 & -0.994 & & -0.769 & -0.236 \\
\hline & & $(2.652) * * *$ & $(2.636)^{* * *}$ & & (1.615) & $(4.441)^{* * *}$ \\
\hline \multirow[t]{2}{*}{ D_GEO } & & -0.085 & -0.088 & & -0.007 & 0.082 \\
\hline & & $(0.294)$ & $(0.302)$ & & $(0.020)$ & $(1.750)^{*}$ \\
\hline \multirow[t]{2}{*}{ D_INDSP } & & -0.442 & -0.501 & & 0.158 & 0.121 \\
\hline & & $(0.689)$ & $(0.765)$ & & $(0.305)$ & $(2.390)^{* *}$ \\
\hline \multirow[t]{2}{*}{ D_TRET } & & -0.161 & -0.171 & & -0.224 & -0.142 \\
\hline & & $(0.269)$ & $(0.283)$ & & $(0.334)$ & $(2.333)^{* *}$ \\
\hline \multirow[t]{2}{*}{ LOG(SIZE) } & & & & -0.018 & 0.212 & 0.004 \\
\hline & & & & $(0.230)$ & $(2.511)^{* *}$ & $(0.297)$ \\
\hline \multirow[t]{2}{*}{ LOG(IC_SIZE) } & & & & 0.417 & 0.362 & -0.029 \\
\hline & & & & $(2.705)^{* * *}$ & $(2.051)^{* *}$ & (1.003) \\
\hline \multirow[t]{2}{*}{ MAINT_FEES } & & & & -180.136 & -206.171 & 30.945 \\
\hline & & & & $(2.072)^{* *}$ & $(2.039)^{* *}$ & $(3.310)^{* * *}$ \\
\hline \multirow[t]{2}{*}{ SALES_FEES } & & & & -219.451 & -269.180 & 34.669 \\
\hline & & & & $(2.322)^{* *}$ & $(2.609)^{* * *}$ & $(3.718)^{* * *}$ \\
\hline \multirow[t]{2}{*}{ D_LOADS } & & & & 0.828 & 0.515 & 0.072 \\
\hline & & & & $(1.830)^{*}$ & (1.083) & (1.062) \\
\hline \multirow[t]{2}{*}{ D_INS } & & & & -0.656 & -0.748 & 0.018 \\
\hline & & & & (1.093) & (1.140) & $(0.276)$ \\
\hline \multirow[t]{2}{*}{ D_CONS } & & & & -1.755 & -2.130 & -0.139 \\
\hline & & & & $(2.165)^{* *}$ & $(2.470)^{* *}$ & $(3.411)^{* * *}$ \\
\hline \multirow[t]{2}{*}{ D_IND } & & & & 2.462 & 2.856 & -0.202 \\
\hline & & & & $(2.969)^{* * *}$ & $(3.319)^{* * *}$ & $(3.276)^{* * *}$ \\
\hline \multirow[t]{2}{*}{ D_POS } & & & & 1.786 & 1.132 & 0.008 \\
\hline & & & & $(3.483)^{* * *}$ & $(2.516)^{* *}$ & $(0.248)$ \\
\hline \multirow[t]{2}{*}{ D_NEG } & & & & 1.255 & 0.602 & -0.009 \\
\hline & & & & $(3.827) * * *$ & $(1.982)^{* *}$ & $(0.185)$ \\
\hline $\begin{array}{l}\text { No. of } \\
\text { Observations }\end{array}$ & 882 & 882 & 882 & 882 & 882 & 882 \\
\hline Pseudo R ${ }^{2}$ & 0.0058 & 0.1765 & 0.1781 & 0.3123 & 0.4136 & 0.6940 \\
\hline
\end{tabular}


Table VI. The Causes of Performance Fee Provisions for Equity Funds

The results of five logistic models that aspire to explain performance fee provisions for equity funds are shown. The independent variables are described in Panels A and B of Table VI. The last column illustrates the results of an OLS model designed to explain the management fee using the same set of variables. Data on funds' characteristics at the end of 2004 are from Assogestioni (2004). Standard Errors have been estimated by clustering the observations within investment companies. Significance at the $1 \%, 5 \%, 10 \%$ levels is marked by $* * *, * *, *$, respectively. $t$-stats in parenthesis.

\begin{tabular}{|c|c|c|c|c|c|c|}
\hline & $\begin{array}{c}\text { Model 1 } \\
\text { (Signaling) }\end{array}$ & $\begin{array}{l}\text { Model } 2 \\
\text { (Optimal } \\
\text { Contract) }\end{array}$ & $\begin{array}{l}\text { Model } 3 \\
\text { M1+M2 }\end{array}$ & $\begin{array}{c}\text { Model } 4 \\
\text { (Strategic } \\
\text { Pricing) } \\
\end{array}$ & $\begin{array}{l}\text { Model } 5 \\
\text { (Global) }\end{array}$ & $\begin{array}{c}\text { Management } \\
\text { Fee }\end{array}$ \\
\hline Constant & $\begin{array}{c}1.562 \\
(3.833)^{* * *}\end{array}$ & $\begin{array}{c}1.812 \\
(3.533)^{* * *}\end{array}$ & $\begin{array}{c}1.814 \\
(3.502)^{* * *}\end{array}$ & $\begin{array}{l}-2.478 \\
(0.793)\end{array}$ & $\begin{array}{l}-3.255 \\
(1.090)\end{array}$ & $\begin{array}{c}1.707 \\
(7.579)^{* * *}\end{array}$ \\
\hline REWARD/RISK & $\begin{array}{l}-0.024 \\
(0.142)\end{array}$ & & $\begin{array}{l}-0.011 \\
(0.054)\end{array}$ & & $\begin{array}{c}-0.548 \\
(2.082) * *\end{array}$ & $\begin{array}{c}-0.030 \\
(1.958)^{*}\end{array}$ \\
\hline D_Euro Zone & & $\begin{array}{l}-0.254 \\
(0.401)\end{array}$ & $\begin{array}{l}-0.247 \\
(0.359)\end{array}$ & & $\begin{array}{l}-0.212 \\
(0.278)\end{array}$ & $\begin{array}{c}0.071 \\
(0.833)\end{array}$ \\
\hline D_European Eq. & & $\begin{array}{c}0.092 \\
(0.382)\end{array}$ & $\begin{array}{c}0.090 \\
(0.366)\end{array}$ & & $\begin{array}{l}-0.326 \\
(0.625)\end{array}$ & $\begin{array}{c}0.003 \\
(0.047)\end{array}$ \\
\hline D_USA Eq. & & $\begin{array}{c}0.439 \\
(0.683)\end{array}$ & $\begin{array}{c}0.437 \\
(0.678)\end{array}$ & & $\begin{array}{c}0.675 \\
(0.639)\end{array}$ & $\begin{array}{c}0.022 \\
(0.393)\end{array}$ \\
\hline D_Pacific Eq. & & $\begin{array}{c}0.203 \\
(0.308)\end{array}$ & $\begin{array}{c}0.198 \\
(0.298)\end{array}$ & & $\begin{array}{l}-0.414 \\
(0.393)\end{array}$ & $\begin{array}{c}0.002 \\
(0.037)\end{array}$ \\
\hline D_Emerging Markets & & $\begin{array}{l}-0.308 \\
(0.730)\end{array}$ & $\begin{array}{l}-0.307 \\
(0.703)\end{array}$ & & $\begin{array}{c}0.537 \\
(0.634)\end{array}$ & $\begin{array}{c}0.160 \\
(2.758)^{* * *}\end{array}$ \\
\hline D_International Eq. & & $\begin{array}{l}-0.407 \\
(1.137)\end{array}$ & $\begin{array}{l}-0.408 \\
(1.140)\end{array}$ & & $\begin{array}{l}-0.046 \\
(0.079)\end{array}$ & $\begin{array}{c}0.075 \\
(1.137)\end{array}$ \\
\hline D_Country Specific & & $\begin{array}{c}-1.995 \\
(2.613) * * *\end{array}$ & $\begin{array}{c}-1.994 \\
(2.583)^{* * *}\end{array}$ & & $\begin{array}{l}-1.013 \\
(1.429)\end{array}$ & $\begin{array}{c}0.438 \\
(3.619)^{* * *}\end{array}$ \\
\hline D_Consumer Goods & & $\begin{array}{l}-0.896 \\
(1.028)\end{array}$ & $\begin{array}{l}-0.896 \\
(1.028)\end{array}$ & & $\begin{array}{c}0.876 \\
(1.260)\end{array}$ & $\begin{array}{c}0.278 \\
(3.352) * * *\end{array}$ \\
\hline D_Energy & & $\begin{array}{l}-1.119 \\
(1.317)\end{array}$ & $\begin{array}{l}-1.116 \\
(1.284)\end{array}$ & & $\begin{array}{c}0.025 \\
(0.042)\end{array}$ & $\begin{array}{c}0.198 \\
(2.831)^{* * *}\end{array}$ \\
\hline D_Finance & & $\begin{array}{l}-0.560 \\
(0.714)\end{array}$ & $\begin{array}{l}-0.572 \\
(0.770)\end{array}$ & & $\begin{array}{l}-0.162 \\
(0.294)\end{array}$ & $\begin{array}{c}0.153 \\
(2.273)^{* *}\end{array}$ \\
\hline D_Health Care & & $\begin{array}{l}-1.119 \\
(1.447)\end{array}$ & $\begin{array}{l}-1.134 \\
(1.456)\end{array}$ & & $\begin{array}{l}-0.300 \\
(0.405)\end{array}$ & $\begin{array}{c}0.147 \\
(2.226)^{* *}\end{array}$ \\
\hline D_ Information Tech. & & $\begin{array}{c}0.490 \\
(0.539)\end{array}$ & $\begin{array}{c}0.470 \\
(0.462)\end{array}$ & & $\begin{array}{c}0.797 \\
(0.526)\end{array}$ & $\begin{array}{c}0.129 \\
(2.075)^{* *}\end{array}$ \\
\hline D_Telecom. Services & & $\begin{array}{l}-0.714 \\
(0.703)\end{array}$ & $\begin{array}{l}-0.725 \\
(0.696)\end{array}$ & & $\begin{array}{l}-1.074 \\
(1.633)\end{array}$ & $\begin{array}{c}0.029 \\
(0.348)\end{array}$ \\
\hline D_Other Industries & & $\begin{array}{l}-0.346 \\
(0.424)\end{array}$ & $\begin{array}{l}-0.347 \\
(0.426)\end{array}$ & & $\begin{array}{c}1.168 \\
(1.648)^{*}\end{array}$ & $\begin{array}{c}0.195 \\
(3.074)^{* * *}\end{array}$ \\
\hline D_Other & & $\begin{array}{l}-0.426 \\
(0.478)\end{array}$ & $\begin{array}{l}-0.427 \\
(0.474)\end{array}$ & & $\begin{array}{c}1.359 \\
(1.060)\end{array}$ & $\begin{array}{c}0.076 \\
(1.069)\end{array}$ \\
\hline LOG(SIZE) & & & & $\begin{array}{c}0.586 \\
(3.394)^{* * *}\end{array}$ & $\begin{array}{c}0.800 \\
(4.273)^{* * * *}\end{array}$ & $\begin{array}{c}0.035 \\
(1.537)\end{array}$ \\
\hline LOG(IC_SIZE) & & & & $\begin{array}{c}0.492 \\
(1.871)^{*}\end{array}$ & $\begin{array}{c}0.509 \\
(2.025)^{* *}\end{array}$ & $\begin{array}{l}-0.025 \\
(0.641)\end{array}$ \\
\hline MAINT_FEES & & & & $\begin{array}{l}-423.625 \\
(3.571)^{* * *}\end{array}$ & $\begin{array}{c}-454.669 \\
(3.835)^{* * *}\end{array}$ & $\begin{array}{c}30.628 \\
(2.673)^{* *}\end{array}$ \\
\hline SALES_FEES & & & & $\begin{array}{l}-384.259 \\
(2.087)^{* *}\end{array}$ & $\begin{array}{l}-435.344 \\
(2.511)^{* *}\end{array}$ & $\begin{array}{c}27.657 \\
(2.720)^{* * *}\end{array}$ \\
\hline D_LOADS & & & & $\begin{array}{c}0.337 \\
(0.417)\end{array}$ & $\begin{array}{c}0.430 \\
(0.561)\end{array}$ & $\begin{array}{c}0.021 \\
(0.236)\end{array}$ \\
\hline D_CONS & & & & $\begin{array}{c}-3.826 \\
(3.147)^{* * *}\end{array}$ & $\begin{array}{c}-4.448 \\
(3.846)^{* * *}\end{array}$ & $\begin{array}{c}-0.200 \\
(3.565)^{* * *}\end{array}$ \\
\hline D_IND & & & & $\begin{array}{c}2.634 \\
(1.910)^{*}\end{array}$ & $\begin{array}{c}3.126 \\
(2.222)^{* *}\end{array}$ & $\begin{array}{c}-0.254 \\
(2.823)^{* * *}\end{array}$ \\
\hline D_POS & & & & $\begin{array}{c}0.915 \\
(1.806)^{*}\end{array}$ & $\begin{array}{c}1.173 \\
(2.032)^{* *}\end{array}$ & $\begin{array}{l}-0.045 \\
(1.667)\end{array}$ \\
\hline D_NEG & & & & $\begin{array}{c}0.106 \\
(0.235) \\
\end{array}$ & $\begin{array}{c}0.165 \\
(0.350) \\
\end{array}$ & $\begin{array}{l}-0.022 \\
(0.490) \\
\end{array}$ \\
\hline No. of Observations & 381 & 381 & 381 & 381 & 381 & 381 \\
\hline Pseudo R2 & 0.000 & 0.068 & 0.068 & 0.510 & 0.558 & 0.274 \\
\hline
\end{tabular}


Table VII. Standard Asset Substitution Risk

The table demonstrates the results of OLS regression models explaining funds' risk (standard deviation), return and reward/risk ratio. The independent variables are a dummy set equal to one if the fund charges an incentive fee (D_INC FEE), the management fee (MAN FEE), the natural logarithm of the size of the fund (LOG(SIZE)), three dummy variables that model the ownership structure of the investment company assuming a value of one whenever the company is part of an insurance group (D_INS), is independent (D_IND), or belongs to a consortium of mutual banks (D_CONS). The default case relates to investment companies belonging to banking groups. The last fifteen variables are a collection of dummy variables defined on the different fund objectives according to the official Assogestioni (2004) classification. Data on funds' characteristics at the end of 2004 have been taken from the funds' prospectuses. Risk and return measures have been calculated on monthly observations from January 2005-December 2006 and annualized. Standard Errors have been estimated by clustering the observations within investment companies $(* * *, * *, *$ for significance at the $1 \%, 5 \%, 10 \%$ levels, respectively). t-stats in parenthesis.

\begin{tabular}{|c|c|c|c|c|c|c|}
\hline & $\begin{array}{l}\text { Risk } \\
\text { (A) }\end{array}$ & $\begin{array}{l}\text { Risk } \\
\text { (B) }\end{array}$ & $\begin{array}{l}\text { Return } \\
\text { (A) }\end{array}$ & $\begin{array}{l}\text { Return } \\
\text { (B) }\end{array}$ & $\begin{array}{c}\text { Reward/Risk } \\
\text { (A) }\end{array}$ & $\begin{array}{c}\text { Reward/Risk } \\
\text { (B) }\end{array}$ \\
\hline \multirow[t]{2}{*}{ Constant } & 0.284 & 0.293 & 0.141 & 0.140 & 0.506 & 0.485 \\
\hline & $(10.371) * * *$ & $(7.750) * * *$ & $(10.871)^{* * *}$ & $(8.036) * * *$ & $(19.479)^{* * *}$ & $(15.554) * * *$ \\
\hline \multirow[t]{2}{*}{ D_INC FEE } & 0.030 & 0.026 & 0.010 & 0.004 & 0.007 & -0.016 \\
\hline & $(1.677)$ & (1.349) & (1.224) & $(0.417)$ & $(0.324)$ & $(0.736)$ \\
\hline \multirow[t]{2}{*}{ MAN FEE } & 0.019 & 0.008 & -0.001 & -0.005 & -0.032 & -0.037 \\
\hline & $(1.200)$ & $(0.499)$ & $(0.113)$ & $(0.752)$ & $(2.539)^{* *}$ & $(3.282)^{* * *}$ \\
\hline \multirow[t]{2}{*}{ LOG(SIZE) } & & 0.005 & & 0.004 & & 0.011 \\
\hline & & (1.317) & & $(1.963)^{*}$ & & $(2.208)^{* *}$ \\
\hline \multirow[t]{2}{*}{ D_INS } & & -0.027 & & -0.020 & & -0.035 \\
\hline & & (1.198) & & (1.612) & & $(1.567)$ \\
\hline \multirow[t]{2}{*}{ D_CONS } & & -0.022 & & -0.022 & & -0.063 \\
\hline & & (1.229) & & $(2.281)^{* *}$ & & $(2.540)^{* *}$ \\
\hline \multirow[t]{2}{*}{ D_IND } & & -0.017 & & -0.000 & & 0.017 \\
\hline & & $(1.023)$ & & $(0.019)$ & & $(0.826)$ \\
\hline \multirow[t]{2}{*}{ D_Euro Zone } & -0.062 & -0.057 & 0.007 & 0.009 & 0.090 & 0.096 \\
\hline & $(2.216)^{* *}$ & $(2.266) * *$ & (0.633) & (0.930) & $(2.935)^{* * *}$ & $(3.176)^{* * *}$ \\
\hline \multirow[t]{2}{*}{ D_European Eq. } & -0.082 & -0.084 & 0.010 & 0.009 & 0.142 & 0.142 \\
\hline & $(2.832) * * *$ & $(2.760)^{* * * *}$ & $(1.351)$ & $(1.323)$ & $(10.810)^{* * *}$ & $(11.405)^{* * *}$ \\
\hline \multirow[t]{2}{*}{ D_USA Eq. } & -0.038 & -0.035 & -0.091 & -0.089 & -0.275 & -0.268 \\
\hline & $(1.318)$ & (1.277) & $(12.354)^{* * *}$ & $(12.330)^{* * *}$ & $(12.082)^{* * *}$ & $(11.782)^{* * *}$ \\
\hline \multirow[t]{2}{*}{ D_Pacific Eq. } & 0.032 & 0.030 & -0.011 & -0.011 & -0.084 & -0.081 \\
\hline & $(0.935)$ & $(0.872)$ & (1.421) & (1.335) & $(3.343)^{* * *}$ & $(3.167)^{* * *}$ \\
\hline \multirow{2}{*}{$\begin{array}{l}\text { D_Emerging } \\
\text { Markets }\end{array}$} & 0.317 & 0.317 & 0.116 & 0.119 & 0.015 & 0.025 \\
\hline & $(2.609) * *$ & $(2.609)^{* *}$ & $(6.936) * * *$ & $(7.335) * * *$ & $(0.464)$ & $(0.769)$ \\
\hline \multirow[t]{2}{*}{ D_International Eq. } & -0.065 & -0.062 & -0.039 & -0.035 & -0.061 & -0.051 \\
\hline & $(2.327)^{* *}$ & $(2.326)^{* *}$ & $(6.456) * * *$ & $(6.092) * * *$ & $(3.432)^{* * *}$ & $(2.798)^{* * *}$ \\
\hline \multirow[t]{2}{*}{ D_Country Specific } & 0.033 & 0.035 & 0.028 & 0.029 & 0.001 & 0.003 \\
\hline & $(0.512)$ & $(0.540)$ & $(0.635)$ & $(0.655)$ & $(0.019)$ & $(0.062)$ \\
\hline \multirow[t]{2}{*}{ D_Consumer Goods } & -0.080 & -0.062 & -0.058 & -0.043 & -0.105 & -0.067 \\
\hline & $(2.823) * * *$ & $(2.824)^{* * *}$ & $(4.778)^{* * *}$ & $(3.447)^{* * *}$ & $(2.121)^{* *}$ & $(1.411)$ \\
\hline \multirow[t]{2}{*}{ D_Energy } & 0.068 & 0.079 & 0.026 & 0.035 & -0.033 & -0.009 \\
\hline & $(1.844)^{*}$ & $(2.298) * *$ & (1.248) & (1.588) & $(0.890)$ & $(0.217)$ \\
\hline \multirow[t]{2}{*}{ D_Finance } & -0.068 & -0.058 & -0.022 & -0.012 & -0.005 & 0.020 \\
\hline & $(2.186)^{* *}$ & $(2.237)^{* *}$ & (1.096) & $(0.684)$ & $(0.095)$ & $(0.366)$ \\
\hline \multirow[t]{2}{*}{ D_Health Care } & -0.063 & -0.058 & -0.081 & -0.075 & -0.214 & -0.193 \\
\hline & $(2.177)^{* *}$ & $(2.085)^{* *}$ & $(9.334) * * *$ & $(8.389)^{* * *}$ & $(9.043)^{* * *}$ & $(7.422)^{* * * *}$ \\
\hline \multirow[t]{2}{*}{ D_Information Tech. } & 0.088 & 0.095 & -0.109 & -0.103 & -0.366 & -0.347 \\
\hline & $(2.080)^{* *}$ & $(2.501)^{* *}$ & $(12.346)^{* * *}$ & $(11.535)^{* * *}$ & $(14.319)^{* * *}$ & $(13.763)^{* * *}$ \\
\hline \multirow[t]{2}{*}{ D_Telecom. Services } & -0.131 & -0.125 & -0.082 & -0.074 & -0.168 & -0.145 \\
\hline & $(4.045)^{* * *}$ & $(4.204)^{* * *}$ & $(4.135)^{* * *}$ & $(3.877)^{* * *}$ & $(2.626)^{* *}$ & $(2.382)^{* *}$ \\
\hline \multirow[t]{2}{*}{ D_Other Industries } & -0.064 & -0.056 & -0.058 & -0.051 & -0.127 & -0.107 \\
\hline & $(1.932)^{*}$ & $(1.792)^{*}$ & $(3.151)^{* * *}$ & $(2.790)^{* * *}$ & $(2.321)^{* *}$ & $(1.975)^{*}$ \\
\hline \multirow[t]{2}{*}{ D_Other } & -0.056 & -0.054 & -0.035 & -0.029 & -0.049 & -0.027 \\
\hline & $(1.799)^{*}$ & (1.673) & $(2.739) * * *$ & $(2.441)^{* *}$ & $(0.957)$ & $(0.537)$ \\
\hline Observations & 381 & 381 & 381 & 381 & 381 & 381 \\
\hline R-Squared & 0.316 & 0.321 & 0.568 & 0.582 & 0.561 & 0.573 \\
\hline
\end{tabular}


Table VIII. Portfolio Asset Substitution Risk

Each cell in the table illustrates three data. The first is the number of the investment companies (IC) managing ' $X$ ' funds of the same type charging incentive fees. The second is the average correlation among funds in each one of these groups. The third (in brackets) is the difference between the average correlation recorded in these groups of funds and the correlation found in equally populated groups of similar funds selected randomly $(* * *, * *, *$ for significance at the $1 \%, 5 \%, 10 \%$ levels, respectively). Daily returns in 2004 are used for the estimation. In order to measure the average correlation among funds in the random groups, we have simulated 1,000 extractions for every investment objective and every group size.

\begin{tabular}{|c|c|c|c|c|c|}
\hline \multirow[b]{2}{*}{ Investment Objective } & \multicolumn{5}{|c|}{$\begin{array}{c}\text { IC with a Portfolio of } X \text { Similar Funds and the } \\
\text { Correlation Among Them }\end{array}$} \\
\hline & $X=2$ & $X=3$ & $X=4$ & $X=5$ & $X=6$ \\
\hline Italian Equities & $\begin{array}{c}11 \\
0,900 \\
(0,111)^{* * *}\end{array}$ & $\begin{array}{c}1 \\
0,984 \\
(0,184)^{* * *}\end{array}$ & & $\begin{array}{c}1 \\
0,914 \\
(0,063)^{* *}\end{array}$ & \\
\hline Euro Zone Equities & $\begin{array}{c}2 \\
0,970 \\
(0,378)^{* * *}\end{array}$ & & & & \\
\hline European Equities & $\begin{array}{c}5 \\
0,940 \\
(0,336) * * *\end{array}$ & & $\begin{array}{c}2 \\
0,948 \\
(0,177)^{* * *}\end{array}$ & & $\begin{array}{c}1 \\
0,887 \\
(-0,051)^{* *}\end{array}$ \\
\hline USA Equities & $\begin{array}{c}4 \\
0,965 \\
(0,121)^{* * *}\end{array}$ & & $\begin{array}{c}2 \\
0,935 \\
(0,061)^{*}\end{array}$ & $\begin{array}{c}1 \\
0,934 \\
(0,060)^{* *}\end{array}$ & \\
\hline Pacific Equities & $\begin{array}{c}7 \\
0,768 \\
(0,138)^{* * *} \\
\end{array}$ & & $\begin{array}{c}1 \\
0,846 \\
(0,191)^{* * *} \\
\end{array}$ & & \\
\hline Emerging Markets Equities & & $\begin{array}{c}2 \\
0,659 \\
(0,014) \\
\end{array}$ & $\begin{array}{c}1 \\
0,747 \\
(0,048) \\
\end{array}$ & & \\
\hline International Equities & $\begin{array}{c}6 \\
0,968 \\
(0,198)^{* * *} \\
\end{array}$ & $\begin{array}{c}3 \\
0,949 \\
(0,128)^{* * * *} \\
\end{array}$ & $\begin{array}{c}1 \\
0,942 \\
(0,121)^{* * *} \\
\end{array}$ & & $\begin{array}{c}2 \\
0,953 \\
(0,059)^{* *}\end{array}$ \\
\hline Other & $\begin{array}{c}1 \\
0,937 \\
(0,099) \\
\end{array}$ & & & & \\
\hline Consumer Goods & $\begin{array}{c}2 \\
0,848 \\
(0,086)^{* * *} \\
\end{array}$ & & & & \\
\hline Energy & $\begin{array}{c}1 \\
0,663 \\
(0,005)\end{array}$ & & & & \\
\hline Information Technology & $\begin{array}{c}1 \\
0,992 \\
(0,240)^{* * *}\end{array}$ & $\begin{array}{c}1 \\
0,904 \\
(0,190)^{* * *} \\
\end{array}$ & & & \\
\hline Other Industries & $\begin{array}{c}5 \\
0,748 \\
(0,028)\end{array}$ & $\begin{array}{c}1 \\
0,764 \\
(0,034)\end{array}$ & & & \\
\hline
\end{tabular}




\section{Table IX. Dynamic Asset Substitution Risk}

The results shown refer to the population of 158 equity mutual funds which charge a synchronous performance fee calculated on an annual basis as a function of either their active return or their differential return with respect to an index of comparable funds. Risk-adjusted ratios (RAR) are calculated as the ratio of both spread volatility (Panel A) and of the reciprocal of the correlation coefficient between funds' return and their hurdle variable (Panel B) $x$ days (assessment period) before and after each year's end (performance fee calculation dates). We divide funds in a $2 \times 2$ table according to both their RAR and the size of their absolute cumulated active or differential return from the beginning of each year (from 2001-2003) to $x$ days prior to the same year's end. $\chi^{2}$ tests for the independence of the cells in the $2 \times 2$ table are also reported.

\begin{tabular}{|c|c|c|c|c|c|c|c|}
\hline \multirow[b]{2}{*}{$\begin{array}{l}\text { Assessment } \\
\text { Period }\end{array}$} & \multirow[b]{2}{*}{ Observations } & \multicolumn{2}{|c|}{ Close to the Benchmark } & \multicolumn{2}{|c|}{ Far from the Benchmark } & \multirow[b]{2}{*}{$\chi^{2}$} & \multirow[b]{2}{*}{ P-Value } \\
\hline & & ‘High’ RAR & 'Low' RAR & 'High' RAR & 'Low' RAR & & \\
\hline \multicolumn{8}{|c|}{ Panel A: Spread Volatility } \\
\hline 20 days & 158 & 22.78 & 27.22 & 27.85 & 22.15 & 1.62 & 0.20 \\
\hline 40 days & & 25.95 & 24.05 & 22.78 & 27.22 & 0.63 & 0.43 \\
\hline 60 days & & 27.22 & 22.78 & 23.42 & 26.58 & 0.91 & 0.34 \\
\hline \multicolumn{8}{|c|}{ Panel B: Reciprocal Linear Correlation Coefficient } \\
\hline 20 days & 158 & 23.87 & 27.10 & 27.10 & 21.94 & 1.10 & 0.29 \\
\hline 40 days & & 25.16 & 25.81 & 24.52 & 24.52 & 0.01 & 0.94 \\
\hline 60 days & & 27.10 & 23.87 & 21.29 & 27.74 & 1.47 & 0.22 \\
\hline
\end{tabular}

